\title{
A Study of the Relationship between Corporate Governance and Non-business Real Estate
}

\author{
Changu Jeon, PhD. Candidate, Chungnam National University \\ Hyangmi Choi ${ }^{* *}$, Professor, Chungnam National University
}

\begin{abstract}
$\langle$ Abstract $\rangle$
Corporate non-business real estate can be used for the private benefits of controlling shareholders, but is also likely to enhance shareholder wealth. This study explores the impact of corporate governance to address this contradiction, particularly the ownership-control disparity on non-business real estate. We further examine the moderating effect of foreign blockholders on the relationship, then conduct additional analyses on the relationship between non-business real estate and firm value. The results are as follows. First, the disparity has a consistently positive relationship with non-business real estate, which implies that corporate non-business real estate can be utilized for expropriation for the benefit of controlling shareholders. Second, the relationship between the disparity and non-business real estate is mitigated by foreign blockholders. Third, we find that non-business real estate has a negative relationship with firm value. This result implicates the inefficiency of non-business real estate and the possibility of agency problem. Forth, investment in non-business real estate is likely to decrease firm value, compared with investment in core business. This study revisits and extends corporate governance research in terms of non-business real estate by identifying the presence of agency problems and monitoring effects of outside blockholders.
\end{abstract}

Keywords: Ownership-Control Disparity; Non-business Real Estate; Foreign Blockholders; Moderating Effect; Agency Problem

JEL Classification: G31, G32, G34

\footnotetext{
* This study was conducted with the support of Chungnam National University's academic research fund.

** Corresponding Author. Address: 99 Daehak-ro, Yuseong-gu, Daejeon, Korea, 34134;

E-mail: hmchoi@cnu.ac.kr; Tel: +82-42-821-5584; Fax: +82-42-821-8718.
}

Received: January 6, 2021; Revised: February 22, 2021; Accepted: March 8, 2021 


\section{기업지배구조와 비사업용 부동산과의 관계에 대한 연구"}

전 찬 구 (충남대학교 박사과정)

최 향 미 (충남대학교 부교수) ${ }^{* *}$

기업의 비사업용 부동산은 주주 부를 증대시키는 수익원으로 기능할 수 있는 한편, 지배주주의 사적이익 수단으로도 활용될 수 있다. 본 연구는 소유지배괴리도가 비사업용 부동산에 미치는 영향과 외국인 기관투자자의 조절효과 및 비사업용 부동산과 기업가치와의 관계를 분석하였다. 분석 결과. 첫째 소유지배괴리도가 클수록 비사업용 부동산 비율은 높게 나타났다. 이는 비사업용 부동산을 이용한 대리인 문제의 가능성을 시사한다. 둘째, 외국인투자자는 저성장, 부동산 비관련 업종, 비집단 개별기업에서 소유지배괴리도와 비사업용부동산 간 양(+)의 관계를 완화(-)시키는 것으로 나타났다. 셋째, 기업의 비사업용 부동산은 기업가치를 저하시키는 것으로 나타났다. 넷째, 비사업용 부동산이 대체수단으로 유용한지 여부를 추가 검증하였다. 기업가치 하락이 비사업용 부동산에 대한 유인으로 작용할 수 있으나 시차에 따라 기업가치에 부정적인 영향을 미치고, 본업 수익보다 비사업용 부동산 발생수익이 더 낮은 것으로 나타나 비사업용부동산이 대리인문제 원인으로 작용할 수 있음을 확인하였다. 본 연구는 대리인 문제를 비사업용 부동산 측면에서 규명하였다는 점과 기업의 비목적사업에 대한 외부감시주체의 견제효과를 확인하였다는 점에서 기업지배구조 연구를 확장하고 있다.

핵심 단어 : 소유지배괴리도, 비사업용 부동산, 기관투자자, 조절효과, 대리인문제

JEL 분류기호: G31, G32, G34

* 본 논문에 대해 유익하고 진심어린 조언을 해 주신 두 분의 익명의 심사위원님께 진심으로 감사의 말씀을 드립니다. 본 연구는 충남대학교 학술연구비의 지원에 의하여 수행되었습니다.

** 연락담당 저자. 주소: 대전광역시 유성구 대학로 99 충남대학교, 34134; E-mail: hmchoi@cnu.ac.kr; Tel: 042-821-5584; Fax: 042-821-8718. 


\section{1. 서론}

기업의 경영자원 중 하나인 부동산은 생산수단으로서의 기능뿐만 아니라 그 자체로서 수익원으로도 활용된다. 이에 한국채택국제회계기준(이하 'K-IFRS')에서는 상장기업에 대해 기업의 본업에 사용되는 부동산은 유형자산으로, 자본차익 또는 임대수익 등을 위한 본업 외의 부동산은 투자부동산(이하 '비사업용부동산)으로 분리하여 계상하도록 하고 있다.

부동산은 취득 또는 보유목적과 관계없이 기업 경영에 있어 다른 자산에 비해 투자규모가 크고 기업에 미치는 경제적 효과가 장기적으로 나타난다. 또한 부동산은 매입이나 건설 시 발생하는 자본예산으로서 현금유출이 따르며 직접발생 비용에 대해 법인세 절감효과 등 기업가치에 직·간접적 영향을 미치게 되므로 주주나 경영자 모두에게 중요한 투자의사결정 중 하나이다. 기업은 성장기회 여부에 따라 투자를 결정할 것이며, 부동산 투자 역시 기업가치 제고의 수단으로 활용될 수 있다. 기업의 부동산 관련정보는 투자기회 제공의 신호전달효과를 기대할 수 있으며(McConnell and Muscarella, 1985), 담보제공 능력의 지표로서 자본비용 절감효과를 기대할 수도 있다. 또한 경영자는 경영성과 저하나 기업가치 하락 등 경영환경 변화에 따라 비사업용부동산을 새로운 수익원, 즉 자본차익과 임대수익을 목적으로 보유 부동산의 리모델링이나 신규매입이라는 의사결정을 할 수 있다.

경영자는 부동산을 매입, 매각 또는 임대 시 고가로 매입하거나 저가 매각 또는 시세보다 저렴한 임대 등의 경영판단을 할 수가 있다. 예를 들어, 비사업용부동산을 감정평가액 보다 낮은 가격으로 매각한다거나, 비용절감 차원에서 장기 방치 또는 공실의 비사업용부동산을 시세보다 저렴한 임대보증금 또는 임대료로 임대 할 수도 있을 것이다. 그러나 시세대비 큰 폭의 거래가격 차이는 주주 및 기업가치 훼손으로 이어질 우려도 있으며, 거래 상대방의 주체에 따라 부당거래로 의심받을 여지가 있고, 이는 대리인문제로 연결될 가능성이 존재한다. 이처럼 시세차이의 부동산 거래는 그 기업이 처한 경영상황에 따라 경영자의 정상적인 경영활동으로도 사적이익추구를 위한 배임행위로서도 해석될 수 있는 법적으로 정치하게 다루어져야 할 대상이다.1) 부동산은 그 목적이 사업용이든 비사업용이든 하나의 투자자원으로서 취득 및 처분에 대해 대부분의 기업에서 이사회 의결사항으로 정하고 있다. 그러나 58개 공시대상기업집단, 266 개 상장회사에서 이사회의 원안가결율이 $99.73 \%$ 라는 사실을 감안하면 이사회의 경영견제 기능을 기대하기 어려운 것이 현실이다.2) 또한 부동산 임대결정은 취득 및 처분과는 달리

1) 계열회사에 대한 저가의 부동산 전대행위에 대해 2심에서는 부당 내부거래로 위법하다고 판시(서울고법 2004. 1. 13)한 반면, 3심에서는 원심을 파기 환송한 판례(대법원 2005. 5. 13)와 경영상황에 비추어 볼 때 부동산 저가매각은 업무상 배임에 해당한다는 판례(대법원 2013. 9. 26) 등 기업의 부동산 거래는 정상적인 경영활동과 위법행위의 양면성을 지니고 있다.

2) 공정거래위원회의 '2020년 공시대상기업집단 지배구조 현황 공개(2020. 12. 9일 보도)'에 따르면 최근 1년간(2019. 5. 15 2020. 5. 1) 이사회 안건 총 6,271건 중 조건부 및 수정의결을 포함한 원안가결은 6,254건으로 99.73\%에 달한다. 또한 이사회 안건 중 대규모 내부거래 관련 안건은 총 692 건 중 단 1 건을 제외하고 원안가결 되었으며, 사익편취 규정대상에 해당하는 상장회사의 경우에는 원안가결 율이 $100 \%$ 인 것으로 나타났다. 
A Study of the Relationship between Corporate Governance and Non-business Real Estate

중요자산의 처분 및 양도의 경영행위가 아니므로 이사회 결의3)는 선택적 사항이라 할 수 있다. 뿐만 아니라 상장기업의 부동산에 대한 취득 및 처분은 자율공시 사항으로 의무공시에 비해 외부감시주체의 견제가 상대적으로 자유로울 수 있으며, 부동산은 치열한 경쟁상품시장에 비해 비경합성으로 인해 시장규율의 영향을 덜 받을 수 있다.

이러한 제반여건은 지배주주나 경영자가 본업과 무관한 부동산 투자를 통해 규모를 확장하거나, 비사업용부동산을 친인척, 계열사 등 이해관계자 간 비정상적인 증여, 매매나 임대차 등을 통해 사적이익을 추구하게 할 수 있으며, 이는 대리인 문제를 야기하고 외부주주의 이익을 저해할 수 있는 여지를 제공한다(Jensen, 1986; Jensen and Murphy, 1990; Shleifer and Vishny, 1997; La Porta et al., 1999; Kim and Cho, 2008; Choi and Cho, 2012; Kim et al., 2015). 특히 소유지배괴리가 큰, 즉 상대적으로 경영자와 지배주주의 지분이 적은 기업에서 경영자는 본인의 지배권 확보나 사적 거래를 통한 이익향유 등을 위해 비경쟁적 재화인 비사업용부동산을 이용할 개연성이 높다.

관련하여 Choi and Cho(2012)는 소유지배괴리가 큰 우리나라 대규모기업집단의 경우, 소유경영을 겸하는 지배주주는 과잉투자 또는 터널링의 수단으로 고정자산에 투자하고 이를 통해 사적이익을 추구할 수 있음을 지적하였으며, $\operatorname{Kim}$ and $\operatorname{Kim}(2015)$ 은 유가증권시장 상장기업을 대상으로 기업의 비사업용부동산과 기업가치와의 관계에 대한 연구에서 비사업용 부동산이 자산 효율성 저하 및 대리인비용 유발로 기업가치를 하락시킨다고 보고하였다. 또한 시민단체에서는 재벌기업의 부동산 보유에 따른 불로소득 및 본업을 위한 소극적인 경영활동에 대해 비판적 시각을 견지하고 있다(경실련, 2018.10.17일자 보도자료4); 참여연대, 2020.1.7. 이슈리포트5)).

한편, 기관투자자는 소액주주보다 정보력과 분석력에서 우위에 있으며, 자금 수탁자의 재산보호와 이익환원을 위해 선량한 관리자로서의 의무를 다하여야 하는 외부감시 주체이다. 따라서 기관투자자는 주주이익에 해가 될 수 있는 안건에 대해 주총에서의 반대의결권 행사 등으로 적극적인 경영감시 및 견제 역할을 수행한다. 하지만 국내기관투자자는 대부분 포트폴리오 투자자 이거나 대규모기업집단의 계열사로서 피투자기업과의 이해관계를 고려할 때 적극적인 경영견제 유인이 적을 수 있다. 이에 비해 외국인투자자는 피투자기업과의 관계에서 자유롭고

3) 상법 제393조(이사회의 권한) (1) 중요한 자산의 처분 및 양도, 대규모 재산의 차입, 지배인의 선임 또는 해임과 지점의 설치.이전 또는 폐지 등 회사의 업무집행은 이사회의 결의로 한다.

4) “재벌대기업의 부동산투기원인은 (1) 공장 등 설비투자가 필요없고, (2) 빌딩 등 사무공간이 필요 없으며, (3) 상시 인력고용의 부담도 없고, (4) 토지가격 상승으로 인한 불로소득 지대추구, 토지를 이용한 분양수익, 임대수익 등 생산활동 보다 더 큰 이익이 발생했기 때문..중략... 재벌과 대기업이 설비투자를 외면하고 부동산투기에 몰두한 지난 10년간 부동산거품이 커지고 아파트값 거품과 임대료 상승 등 부작용이 속출하고 있다. 재벌이 부동산 투기로 불로소득을 노리고 업무용.사업용 토지가 아닌 비업용 토지를 보유해도 문제 삼지 않았다."

5) “토지분 종합부동산세 상위 30 개 법인이 소유하고 있는 토지는 시세 기준으로 100 조 원을 넘을 것으로 보입니다..중략... 토지에 대한 동일한 양도차익이 발생할 경우 법인의 양도소득세액이 개인보다 적습니다..중략 $\cdots$ 토지소유 집중이 개인보다는 법인단위로 이루어질 가능성을 높게 만들고 있습니다.” 
한국증권학회지 제 50 권 3호 (2021)

경영감시 기능이 국내기관투자자보다 우월하다(Khanna and Palepu, 1999). 따라서 비사업용 부동산이 기업의 자원효율성에 저해가 되고, 대리인 비용의 원인이 되며 기업가치를 저하시키는 요인으로 작용한다면 외국인투자자는 기업의 비사업용부동산에 대한 효율적인 경영감시의 주체가 될 수 있다.

이에 본 연구는 기업의 소유지배괴리도가 기업의 비사업용부동산에 미치는 영향과 외국인 투자자가 이에 대한 견제역할을 하는지를 분석하고, 기업의 비사업용부동산이 기업가치에 미치는 영향을 규명하고자 하였다.

저성장기업은 고성장기업보다 상대적으로 비사업용 부동산에 대한 투자 및 보유유인이 높을 개연성이 있으며, 건설업이나 임대업과 같은 부동산 관련업종은 비사업용부동산에 대한 회계처리의 대체 가능성6)으로 인해 실증분석이 왜곡될 수 있다. 또한 대규모기업집단 소속기업은 비집단기업에 비해 상대적으로 더 자주 시장 감시 및 공정거래에 대한 제도적 감시 장치의 적용을 받는다. 따라서 본 연구는 성장성 기준, 부동산 관련업종 여부 및 대규모기업집단 여부로 나누어 실증분석을 수행하였다.

본 연구의 결과는 다음과 같다. 첫째, 소유지배괴리도와 비사업용부동산 간 양(+)의 유의적인 결과가 나타났으며, 이는 소유지배괴리도가 높은 기업일수록 비사업용 부동산이 증가함을 의미한다. 그러나 고성장기업은 소유지배괴리도와 비사업용 부동산 간 통계적으로 유의하지 않았고, 이는 고성장기업의 경우 본연의 사업용 자산수익이 높기 때문에 비사업용부동산에 대한 유인이 저성장기업에 비해 상대적으로 낮다고 해석할 수 있다.

둘째, 외국인투자자는 소유지배괴리도의 증가가 비사업용부동산을 증가시키는 양(+)의 관계를 완화(-)시키는 것으로 나타났다. 특히 저성장기업, 부동산 비관련업, 그리고 대규모기업집단이 아닌 기업에서 유의적인 양(+)의 조절효과를 확인할 수 있었다. 그러나 고성장기업, 부동산 관련업 및 대규모기업집단에서는 이러한 조절효과가 통계적으로 유의하지 않았는데, 이는 성장성, 업종특성, 그리고 제도적 규제 수준에 따라 비사업용 부동산에 대한 과잉투자가 차별적임을 시사한다.

셋째, 기업의 비사업용부동산은 기업가치를 하락(-)시키는 것으로 나타났다. 비사업용 부동산은 대체투자 수단으로서도 기능할 수 있지만, 사업용 자산 대비 기회손실을 가져온다는 점에서 기업가치에 도움이 되지 않는다고 할 수 있다.

넷째, 비사업용부동산이 대체투자 수단으로서의 효율성 확인을 위해 기업가치와 비사업용 부동산 상호 간의 영향을 시차분석을 통해 분석하였다. 분석결과, 1 기간 전의 기업가치 하락이 비사업용부동산에 대한 유인으로 작용하지만 1 기간 후에는 기업가치를 하락시키는 것으로

6) 부동산업을 영위하는 기업은 부동산의 목적에 따라 재고자산, 고정자산, 투자부동산으로 계상 할 수 있다. 분양을 목적으로 하는 자산은 재고자산으로, 사무실 등 업무용 부동산은 고정자산으로, 자본차익이나 임대수익 목적의 부동산은 투자부동산으로 계상하여야 한다. 그러나 부동산의 목적이 변경될 경우(예를 들어 분양을 목적으로 한 아파트나 토지가 미분양 되어 임대로 전환할 경우와 같이), 기존 재고자산으로 계상되었던 부동산을 투자부동산으로 대체처리가 가능하다(K-IFRS 문단 제1040호). 
나타났다. 또한 비사업용부동산 발생수익률이 본업을 통한 수익률에 비해 낮게 나타남으로써, 비사업용부동산이 새로운 수익을 창출하는 대체투자 수단이기보다 경영자 및 지배주주의 사적 동기를 위한 수단으로 사용될 수 있음이 확인되었다.

본 연구는 최근 사회적 이슈가 되고 있는 기업의 비사업용부동산에 대해 대리인 문제 관점으로 실증분석 하였다는 점에서 의의를 찾을 수 있다. 또한 기존의 소유구조와 기업 투자와의 관련 연구는 연구개발투자 또는 고정자산 중심으로 진행되어왔으나 본 연구는 소유 및 지배구조와 비사업용부동산, 그리고 기업가치 관련성에 집중하였으며, 기업의 성장성, 부동산 관련성 및 대규모기업집단 여부 등 기업의 세부적인 특성을 반영하여 분석을 수행하였고 더불어 비사업용 부동산에 대한 외국인투자자의 경영 감시효과가 존재하는지를 실증하였다는 데에서 의의를 찾을 수 있다.

본 논문의 구성은 다음과 같다. 제 2 장에서는 소유지배괴리도와 기업부동산과의 관계에 대한 기존연구를 살펴보고 제 3 장에서는 연구내용 및 분석방법을, 제 4 장에서는 분석결과를, 결론에서 연구결과 및 시사점을 제시한다.

\section{2. 이론적 배경 및 선행연구}

대리인 이론은 경영자와 주주 간 서로 상충되는 이해관계로 인해 경영자가 주주의 이익을 위한 의사결정 보다 본인의 이익을 위한 의사결정을 하는 것에서 야기되는 문제로 정의되며, 과잉투자, 과소투자, 터널링 등 다양한 형태(Choi and Cho, 2012; Lee and Byun, 2016a; Park, 2017)로 나타난다. 특히 소유지배괴리도가 클 때, 즉 경영자 혹은 지배주주의 지분이 상대적으로 적은 반면 지배권이 강할 때 대리인 문제는 심화될 수 있으며 이에 따라 기업가치 저하를 가져올 수 있다(Jensen and Meckling, 1976; Loderer and Martin, 1997; Claessens et al., 2002; Lemmon and Lins, 2003). 소유지배괴리로 인한 지배주주와 외부주주 간 대리인 문제(Shleifer and Vishny, 1997; La Porta et al., 2002; Choi and Cho, 2012)는 동아시아 국가에서 두드러지게 나타나고 있으며(Claessens et al., 2000), 적은 지분의 지배주주가 다양한 형태로 소액주주의 이익을 침해하는 것으로 기존 연구에서 밝히고 있다.

국내 대규모기업집단의 지배주주는 3.5\%에 불과한 지배주주의 지분으로 계열사와 비영리법인 등을 이용하여 훨씬 많은 경영권을 행사하고 있으며(Park, 2017), Kwon and Choi(2013)는 소유지배괴리와 이익조정에 대한 연구를 통해 직접소유 지분뿐 아니라 간접소유 지분에도 이익조정을 한다는 결과를 보고하여 지배주주의 영향력을 규명하였다. 관련연구로 Yoon(2005)과 Choi and Cho(2011b)는 소유지배괴리도와 연구개발투자 간 음(-)의 관계를 밝힘으로써 고위험 투자를 회피하는 경영자 안주현상의 대리인 문제를 주장하였다. 또한 Kwon(2012)은 재벌기업 에서 계열사 간 부의 이전을 통한 대리인 문제를 주장하였고, Blanchard et al.(1994)과 Kim et al.(2010)은 소수지분의 경영자는 사업다각화를 통해 경영자 본인의 위험을 분산시키고 있음을 실증하며 경영자참호가설을 지지하였다. 기업부동산 관련연구로 $\mathrm{Kim}$ et al.(2015)은 유가증권 시장 상장기업을 대상으로 한 연구에서 지배권이 증가할수록 기업의 사업용 부동산과 비사업용 
한국증권학회지 제50권 3호 (2021)

부동산이 증가한다는 결과를 통해 대리인 문제를 제기, 경영자가 지배권 확보나 위험회피 또는 터널링 등 사적이익을 목적으로 부동산을 활용할 수 있음을 보고하였다.

완전경쟁시장은 동질의 재화에 다수의 공급자와 수요자가 존재하며 해당 재화에 대한 정보와 지식을 갖추고 시장 진출입이 자유로워야함을 요건으로 한다. 이러한 측면에서 부동산은 국지성과 부증성으로 인해 다른 재화에 비해 공급이 비탄력적이며, 이질성으로 인해 수요자와 공급자 간 정보비대칭이 심한 재화일 뿐 아니라 대체제가 거의 없는 독과점적 요소를 띄고 있어 불완전경쟁시장이라 할 수 있다(Kim et al., 2007; Lee, 2007, 2019). 또한 부동산은 일물일가의 법칙이 적용되지 않는다. 왜냐하면 부동산의 모든 조건이 동일할지라도 위치에 따른 접근성, 일조권 등 개별요인과 개발행위에 대한 법적제한으로 인해 동질의 재화라 할 수 없기 때문이다. 따라서 부동산은 일반재화의 가격과 비교하여 공정가격이나 시장가격의 책정이 어려울 뿐 아니라 비사업용부동산의 취득 및 관리비용은 법인세법에 따라 손금으로 인정받지 못함7)으로써 법인세 절감효과를 기대하기 어려운 자산으로 사업용부동산에 비해 투자매력이 덜하다 할 수 있다. 이러한 불리한 여건에도 불구하고 경영자는 가격에 대한 정보비대칭성을 이용하여 비사업용 부동산에 대한 투자유인이 생길 수 있으며 고가매입이나 저가의 임대차 등을 통해 사적이익의 수단으로 활용할 수 있다. 특히 경영자의 지분이 적을 경우, 지배권 확보나 사적유용을 위해 이러한 유인은 더 크게 작용할 수 있다.

경영자 지분과 비사업용부동산의 관계는 기업의 특성에 따라 각기 다르게 나타날 수 있는데, 고성장기업은 경영자 지분이 적을지라도 본연 사업으로 인한 이익이 더 크다면 대체 투자에 대한 유인이 적을 것인데 반해, 저성장기업에서 지분이 적은 경영자는 성장성 정체나 저하에 따른 대체 투자로 비사업용부동산을 대안으로 선택할 수도 있음과 함께 경영자 본인의 사적이익을 위해 이용할 수도 있다. 또한 건설업이나 부동산임대업을 본업으로 하는 기업과 그렇지 않은 기업에 따라 적은 지분의 경영자는 비사업용부동산을 각각 다른 목적으로 활용할 수 있으며, 기업집단은 비집단에 비해 시장이나 제도적 감시수준이 높아 경영자 지분과 비사업용부동산과의 관계에 차이가 있을 수 있다. 다시 말해 성장성이 높은 기업과 부동산관련업종, 그리고 대규모 기업집단에서는 소유지배괴리도와 비사업용부동산과의 관계가 통계적으로 유의하지 않거나 주가설과 반대의 결과를 예상해 볼 수 있다. 이에 본 연구는 아래와 같이 가설을 설정하고 실증분석을 통해 규명하고자 한다.

가설 1: 소유지배괴리도가 클수록 기업의 비사업용부동산은 증가할 것이다.

가설 1-1: 소유지배괴리도가 비사업용부동산에 미치는 영향은 기업의 성장성에 따라 차별적일 것이다.

가설 1-2: 소유지배괴리도가 비사업용부동산에 미치는 영향은 부동산 관련성에 따라 차별적일 것이다.

7) 법인세법 제 27 조(업무와 관련 없는 비용의 손금불산입) 내국법인이 지출한 비용 중 다음 각 호의 금액은 각 사업연도의 소득금액을 계산할 때 손금에 산입하지 아니한다. 1. 해당 법인의 업무와 직접 관련이 없다고 인정되는 자산으로서 대통령령으로 정하는 자산을 취득.관리함으로써 생기는 비용 등 대통령령으로 정하는 금액. 
A Study of the Relationship between Corporate Governance and Non-business Real Estate

가설 1-3: 소유지배괴리도가 비사업용부동산에 미치는 영향은 대규모기업집단여부에 따라 차별적일 것이다.

기업의 투자결정은 장기적인 성과와 성장을 결정짓는 요인으로서 투자효율성을 높여 주주에게 부를 환원하기도 하지만 그렇지 않을 경우에는 기업의 쇠퇴 원인이 되기도 한다(Lim et al., 2014). Myers(1977)와 Bizjak et al.(1993)은 투자기회와 경영자의 기회주의적 행태에 대한 관련성 연구에서, 경영자는 투자기회에 대한 선택에 있어 많은 재량권을 행사하는 것으로 밝혀졌다. 경영자는 투자기회에 대한 정보를 이용하여 본인의 지위, 명성이나 보상(Ball, 2009; Kothari et al., 2009; Kim et al., 2011b) 및 지배권 강화에 재량권을 활용함으로써 대리인 문제를 발생시킬 수 있다. 부동산 역시 경영자의 기회주의적 행태를 유발하여 이러한 문제를 야기할 수 있는 원천이 될 수 있다. 따라서 대리인 문제를 완화시켜 기업가치 하락을 방지하고 주주권 보호에 기여할 수 있도록 철저한 경영감시가 요구된다.

기관투자자는 개인투자자에 비해 대규모 운영자금에 대한 규모의 경제를 바탕으로 정보력과 분석력을 갖춘 외부감시주체이며(Shleifer and Vishny, 1989), 자금의 수탁자로서 신의성실 원칙에 따라 기업의 경영의사결정에 대한 철저한 감시와 견제가 요구된다. 이러한 원칙하에 관련연구 대부분은 기관투자자의 경영감시가 기업가치 제고에 기여하는 것으로 보고하고 있다(Chung et al., 2002; Hartzell and Starks, 2003; Shin et al., 2004; Bebchuk et al., 2009). Bushee(1998)는 기관투자자가 경영자의 근시안적 투자결정에 대한 견제역할을 함으로써 주주의 이익 보호에 기여한다고 하였으며, Bhide(1994)는 기관투자자가 소유자와 경영자의 결탁을 견제함으로써 올바른 경영 의사결정을 견인한다고 주장하였다. 이러한 기관투자자의 감시효과를 위해 Gillan and Starks(2003)는 기관투자자의 충분한 주식지분과 장기 투자가 전제되어야 함을 주장하였으며 Noe(2002)와 Ferreira and Matos(2008)는 기관투자자의 유형 및 독립성 여부에 따라 경영의사결정에 미치는 영향은 다르게 나타날 수 있음을 밝혔다.

한편 국내 기관투자자는 외국인투자자에 비해 경영감시 기능이 상대적으로 취약하다(Park, 2017). 이러한 사실은 주총 안건반대비율에서도 확인할 수 있는데, 외국인투자자의 반대비율이 $8 \%$ 에 인데 반해 국내 기관투자자는 $1 \%$ 에 불과한 것으로 나타났다(한국기업지배구조원). 이러한 행태는 국내 기관투자자가 대규모기업집단의 소속계열사인 경우가 다수인 점을 감안할 때, 피투자기업과의 이해관계에서 비롯되는 것으로 풀이된다. 이에 반해, 외국인투자자는 투자대상 기업과의 관계에 있어 상대적으로 독립적이며, 국내 기관 투자자에 비해 자본력, 정보력 및 분석력에서의 우월성을 바탕으로 효율적인 경영감시를 수행하고 대리인 비용을 낮춰 기업가치 개선에 기여한다(Shleifer and Vishny, 1986; Khanna and Palepu, 1999; Gillan and Starks, 2003; Mitton, 2006; Ferreira and Matos, 2008; Kim et al., 2010; Aggarwal et al., 2011; Choi and Cho, 2011a; Mian and Nagata, 2015). 관련연구로, Park et al.(2004)은 외국인투자자 지분과 접대비 간 음(-)의 관계를 실증하여 외국인투자자가 경영자의 사적소비를 감시하고 대리인비용을 차단함으로써 간접적으로 기업가치를 개선하는 것으로 보고하였으며, Kim and 
한국증권학회지 제 50 권 3호 (2021)

Jung(2011)은 대량 지분보유 외국인투자자는 국내 기관투자자보다 정보비대칭을 완화시키는 데 효과적이며, 기업의 투자에 긍정적인 영향을 미친다는 결과를 내놓았다.

반면에 외국인투자자의 행태에 따라 경영감시를 통해 대리인문제를 해소하기보다는 경영자 와의 결탁 등으로 대리인 문제를 심화시킬 수도 있다는 연구(Kim and Park, 2017)도 존재한다. 외국인투자자가 단기이익만을 추구한다면 기업성장을 위한 장기적인 투자를 저해하고, 과도한 배당을 요구할 수도 있다. Sul and Kang(2006)은 외국인투자자와 국내기업의 투자의사결정과의 관계에 대한 실증연구에서 외국인투자자는 설비투자에 부정적임을 보고하였으며, Park and Lee(2006)는 외환위기 전후의 외국인투자자와 국내기업의 투자 간 관계를 분석한 연구에서, 외환위기 전 외국인투자자는 국내기업의 투자를 감소시켰고, 외환위기 이후에는 유의적이지 않음을 보고하였다. 또한 $\mathrm{Kim}$ and $\mathrm{Cho}(2008)$ 는 외국인투자자와 국내기업의 투자에는 통계적으로 유의한 부(-)의 관계가 있음을 발표하였다. 이러한 연구결과는 외국인투자자의 투자기간을 장단기로 구분하였을 때, 단기성과를 추구하는 외국인투자자의 특징으로 해석할 수 있다. 이처럼 외국인투자자의 경영감시에 대한 연구는 외국인투자자의 양태와 분석기간에 따라 긍정과 부정의 혼재된 결과를 보이고 있다.

부동산은 생산의 중요원천임과 동시에 대체투자 수단으로서, 사용 목적이나 활용 방식에 따라 주주의 이익에 긍정적일 수도, 부정적일 수도 있는 기업의 중요한 자원이며(Barlow and Lawson, 1990; Booth, 2000; Hill, 2001; Krumm and de Vries, 2003), 부동산의 취득·보유 또는 처분은 주주가치에 영향을 미치는 중요한 의사결정 사항이다(Lim and Kim, 2018). 부동산의 목적에 따라, 즉 공장증설을 위한 토지구입 등과 같이 해당 부동산이 본업을 위한 것인지, 경영성과나 기업가치 하락에 따른 대체투자 목적인지, 아니면 경영자의 사적이익향유를 위한 수단인지에 따라 외국인투자자의 감시효과는 차별적일 수 있다.

비사업용부동산 발생수익이 기업의 본업수익에 비해 낮다면 자원의 비효율성의 원인이라는 반증일 것이고, 수익이 없거나 음(-)의 수익이 발생한다면 대리인 문제로 인식할 수 있을 것이다. 따라서 본 연구에서는 외국인투자자의 경영감시에 대한 혼재된 기존연구결과를 감안하여 외국인투자자가 소유지배괴리도와 비사업용부동산과의 관계에서 어떠한 영향을 미치는지 확인하기 위해 다음과 같이 가설을 설정하였다.

가설 2: 외국인투자자는 소유지배괴리도와 비사업용부동산 간 양(+)의 영향을 강화(완화)시킬 것이다.

가설 2-1: 소유지배괴리도와 비사업용부동산간의 관계에서 외국인투자자의 효과는 기업의 성장성에 따라 차별적일 것이다.

가설 2-2: 소유지배괴리도와 비사업용부동산간의 관계에서 외국인투자자의 효과는 부동산 관련성에 따라 차별적일 것이다.

가설 2-3: 소유지배괴리도와 비사업용부동산간의 관계에서 외국인투자자의 효과는 대규모 기업집단 여부에 따라 차별적일 것이다.

기업부동산과 관련된 기존연구는 $\mathrm{K}-\mathrm{IFRS}$ 를 채택(2011년)하기 전 기업회계기준에서 부동산을 
유형자산으로 단일 계상하도록 한 자료를 사용한 것으로, 사업용부동산과 비사업용부동산에 대한 명확성은 떨어진다 할 수 있다. 게다가 기업부동산과 기업가치 관련성에 대한 국내연구는 활발하지 않은 것이 사실이다. Kim and Jung(1993)은 기업부동산 보유비율 증가와 주가수익률 간 음(-)의 관계임을 밝혔으며, 부동산을 과잉투자의 요인으로 해석하고 이로 인한 대리인문제 개연성을 제시하였다. Lee and Cho(2009)와 Kim and Kim(2015)는 기업의 부동산을 보유 부동산과 비사업용부동산으로 나누어 기업가치와의 관련성을 연구하였는데, 보유부동산은 양(+)을, 비사업용부동산과는 음(-)의 관계가 있음을 보고하였다. Kang and $\mathrm{Kho}(2015)$ 는 기업부동산의 포트폴리오 효과를 분석한 연구에서, 기업부동산은 기업의 위험을 낮춰 기업가치를 높이나, 비사업용부동산은 기업가치에 영향을 미치지 못한다는 결과를 제시하였다. Lee and Byun(2016b)은 상품시장의 경쟁수준과 기업부동산 및 기업가치 연관성에 대한 연구에서 경쟁상품일수록 부동산이 증가하고, 부동산의 증가는 경쟁우위 확보의 시그널로 작용하여 궁극적으로 기업가치에 긍정적으로 반응하지만, 비사업용부동산은 기업가치에 부정적이라는 결과를 발표하였다. 이와 같이 기업부동산은 그 목적에 따라 기업가치에 미치는 영향이 차별적임을 알 수 있으며, 특히 비사업용부동산은 기업가치에 부정적이라는 일관된 결과를 제시하고 있다. 그러나 선행연구에서 사용한 비사업용부동산에 대한 자료는 국제회계기준 채택 전의 자료이거나 채택 후의 자료도 양적인 면에서 부족하다는 한계가 있다. 이에 본 연구는 정밀한 분석을 위해

$\mathrm{K}-\mathrm{IFRS}$ 채택 후의 자료를 사용하였으며, 선행연구결과를 바탕으로 아래와 같이 가설을 설정하였다.

가설 3: 기업의 비사업용부동산은 기업가치를 하락시킬 것이다.

가설 3-1: 기업의 비사업용부동산이 기업가치에 미치는 영향은 기업의 성장성에 따라 차별적일 것이다.

가설 3-2: 기업의 비사업용부동산이 기업가치에 미치는 영향은 부동산 관련성에 따라 차별적일 것이다.

가설 3-3: 기업의 비사업용부동산이 기업가치에 미치는 영향은 대규모기업집단 여부에 따라 차별적일 것이다.

\section{3. 연구방법}

\section{1 표본 및 자료수집}

본 연구는 K-IFRS에서 사업용부동산과 투자용부동산을 구분 계상하도록 한 2011년부터 2017년까지 총 7년간 유가증권시장 및 코스닥시장에 상장된 12월 결산법인 중 상장폐지 기업, 재무자료 미확인 기업 및 자본잠식 기업을 제외한 총 1,823 개의 제조업 기업을 대상으로 하였다. 표본은 유가증권시장상장 677 개 기업, 코스닥시장상장 1,146 개 기업과 표본 11,160 개(유가증권 시장 4,441개, 코스닥 시장 6,719 개)로 구성하였다.

고성장 기업의 경우, 성장의 원천인 본업에 집중할 것이기에 부동산을 수단으로 하는 이익창출의 유인은 성장성이 낮은 기업에 비해 덜 할 수 있다. $\mathrm{OECD}$ 와 통계청에서는 매출액 성장률 $20 \%$ 
한국증권학회지 제 50 권 3호 (2021)

이상인 기업을 고성장 기업8)으로 정의, 통계에 사용하고 있다. 따라서 본 연구에서는 전년대비 매출액 성장률 $20 \%$ 이상의 기업을 고성장 기업으로, 미만인 기업을 저성장 기업으로 나누어 표본으로 삼았다.

또한 건설업과 부동산업을 영위하는 기업(‘이하 관련업종’)은 부동산이 본업으로서 부동산이 건설중인자산이나 재고자산으로 계상될 뿐 아니라 임대수익 목적의 비사업용부동산으로도 계상되는 대체적인 성격을 띠고 있다. 분양을 목적으로 건설중이거나 건설한 건물이 임대주택으로 용도변경 되면 비사업용부동산으로 계상하는 것을 예로 들 수 있다. 이에 건설업과 부동산업은 다른 업종과 분리하여 분석에 사용하였다.

대규모기업집단은 순환출자 금지 또는 제한, 내부거래를 통한 불공정거래행위 금지 및 채무보증 금지 등 공정거래법에서 네거티브 조항을 규정하고 있으며, 경영관련 사항을 자본시장법에서 모두 공시토록 법제화하고 있다. 이러한 시장 감시제도의 유무를 고려하여 본 연구에서는 대규모기업집단 소속여부에 따라 표본을 분리, 분석에 포함하였다.

소유지배괴리도와 비사업용부동산, 그리고 외국인투자자의 감시효과 및 기업가치와의 관계를 분석하기 위해 통계청 기준 한국산업표준분류 중 대분류에 따라 <표 $1>$ 과 같이 표본을 구성하였다.

〈표 1〉업종별 표본 구성

\begin{tabular}{|c|c|c|c|c|c|c|}
\hline \multirow{2}{*}{ 업종 } & \multicolumn{2}{|c|}{ 전체표본 } & \multicolumn{2}{|c|}{ 고성장 기업 } & \multicolumn{2}{|c|}{ 저성장 기업 } \\
\hline & 표본수 & 비율 & 표본수 & 비율 & 표본수 & 비율 \\
\hline 제조업 & 7,298 & 65.39 & 1,264 & 62.48 & 6,034 & 66.04 \\
\hline 정보통신업 & 1,233 & 11.05 & 247 & 12.21 & 986 & 10.79 \\
\hline 도매 및 소매업 & 972 & 8.72 & 192 & 9.48 & 780 & 8.54 \\
\hline 전문, 과학 및 기술 서비스업 & 655 & 5.87 & 150 & 7.41 & 505 & 5.53 \\
\hline 건설업 및 부동산업 & 367 & 3.29 & 85 & 4.20 & 282 & 3.09 \\
\hline 운수 및 창고업 & 175 & 1.57 & 16 & 0.87 & 159 & 1.74 \\
\hline 전기, 가스 공급, 시설관리업 등 & 222 & 1.98 & 18 & 0.88 & 204 & 2.23 \\
\hline 교육, 예술, 스포츠 등 서비스업 & 140 & 1.25 & 8 & 0.39 & 132 & 1.44 \\
\hline 지주회사, 농·임·어업, 숙박 및 음식점업 & 98 & 0.88 & 43 & 2.08 & 55 & 0.6 \\
\hline 계 & 11,160 & 100 & 2,023 & 100 & 9,137 & 100 \\
\hline
\end{tabular}

총 11,160 개의 표본 중 제조업과 정보통신업이 8,531 개 $76.4 \%$ 로 대다수를 차지하고 있으며, 부동산 관련업종으로 분리하여 분석한 건설업과 부동산업이 367 개 $3.3 \%$ 로 구성되었다. 매출액 성장률 $20 \%$ 이상의 고성장으로 나타난 표본은 총 2,023 개로 제조업이 $62.5 \%, 1,264$ 개였으며 정보통신업이 $12.2 \%, 247$ 개로 나타났다.

본 연구의 독립변수인 소유지배괴리도의 소유지분율과 의결지분율 및 $5 \%$ 이상 외국인투자자 지분율 자료는 금융감독원 전자공시사이트(dart.fss.or.kr)에서 기업별 연도별 정기 사업보고서를

8) Eurostat-OECD Manual on Business Demography Statistics(www.oecd.org/sdd/business-stat), 통계청 기업생멸통계매뉴얼(www.kostat.go.kr). 
A Study of the Relationship between Corporate Governance and Non-business Real Estate

통해 수집하였다. 또한 공시사이트에서 친족 여부 확인이 모호한 주주 정보는 연합뉴스 인물정보와 한국언론진흥재단의 뉴스 통합 데이터베이스인 빅카인즈(www.bigkinds.or.kr)를 통해 확인. 수집하였다. 종속변수로 사용한 비사업용부동산 비율과 토빈 Q 측정을 위한 자료 및 통제변수로 사용한 총자산, 부채비율, 잉여현금흐름, $\mathrm{ROE}$, 배당성향, 업력 등 재무자료 및 기초자료는 한국상장회사협의회 제공 데이터베이스인 TS-2000을 통해 수집하였다.

\section{2 실증모형 및 변수정의}

본 연구는 우선 소유지배괴리도가 비사업용부동산에 미치는 영향을 분석하고 두 변수의 관계에서 외국인투자자의 경영감시 역할을 조명한 후, 소유지배괴리도가 비사업용부동산에 미치는 영향분석에서 추정한 비사업용부동산 비율과 기업가치와의 관계를 분석하여 비사업용 부동산이 기업가치에 어떠한 영향을 미치는지를 실증하였다. 변수로서 비사업용부동산은 비사업용부동산의 전년대비 증감률이나 총자산대비 비사업용부동산 비율을 사용할 수 있다. 본 연구에서는 총자산대비 비사업용부동산 비율을 사용하였는데, 이는 비사업용부동산 증감률의 경우 자산재평가.9)에 따라 분석결과의 왜곡을 가져올 수 있기 때문이다. 총자산대비 비사업용 부동산비율은 비사업용부동산비율이 총자산을 초과할 수 없기 때문에 $0 \%$ 부터 $100 \%$ 사이의 제한된 값을 가지며, 또한 본 연구의 표본은 독립변수인 소유지배괴리도와 종속변수인 비사업용 부동산비율 모두 존재하는 표본이 있는 반면에 소유지배괴리도는 있고 비사업용부동산은 없는 표본 즉, 중도절단된(truncated) 분포로 구성되어 있다. 따라서 소유지배괴리도가 비사업용 부동산비율에 미치는 영향과 두 변수 간 외국인투자자의 감시효과는 토빗 회귀모형으로 시행 하였다.

비사업용부동산이 기업가치에 미치는 영향에 대한 분석은 소유지배괴리도가 비사업용 부동산에 미치는 영향을 회귀분석으로 추정한 비사업용부동산비율을 독립변수로 하고 기업가치 대용치인 토빈 $\mathrm{Q}$ 를 종속변수로 하여 오차항의 이분산성을 고려해 White 방법을 통한 강건한 표준오차(robust standard error)를 사용하여 회귀분석 하였다. 소유지배괴리도가 비사업용 부동산에 미치는 영향과 비사업용부동산이 기업가치에 미치는 영향은 시차를 두고 나타날 수 있음을 고려하여 1 기간 후의 비사업용부동산비율과 토빈 $\mathrm{Q}$ 를 종속변수로 사용하였다. 본 연구의 실증분석 모형은 아래와 같다.

$$
\begin{aligned}
\text { Tobit: } \text { IRE }_{i, t(t+1)}= & \beta_{0}+\beta_{1} \text { Disparity }_{i, t}+\beta_{2} \text { Size }_{i, t}+\beta_{3} R O E_{i, t}+\beta_{4} \text { Debt }_{i, t} \\
& +\beta_{5} F C F_{i, t}+\beta_{6} \text { Dividend }_{i, t}+\beta_{7} \text { Age }_{i, t}+\operatorname{Year}(\text { dum }) \\
& + \text { Industrial }(\text { dum })+\varepsilon_{i, t}
\end{aligned}
$$

9) 본 연구 대상기간인 2011년부터 2017년까지 한국거래소 공시 기준으로 70개(코스피 29, 코스닥 41)의 기업에서 자산재평가가 시행되었다. 또한 자산재평가는 공정거래위원회 공시규정 및 한국거래소 공시규정 중 ‘자율공시' 사항으로서 '자산재평가'가 수행되었을지라도 공시하지 않은 기업이 존재할 수 있다. 따라서 비사업용부동산 증감률을 변수로 사용할 때 회귀분석 결과에 왜곡이 발생할 수 있다. 


$$
\begin{aligned}
& \text { Tobit: } \operatorname{IRE}_{i, t(t+1)}=\beta_{0}+\beta_{1} \text { Disparity }_{i, t}+\beta_{2} \text { Foreign }(\text { dum })_{i, t} \\
& +\beta_{3}[\text { Disparity } \times \text { Foreign }(\text { dum })]_{i, t}+\beta_{4} \text { Size }_{i, t} \\
& +\beta_{5} R O E_{i, t}+\beta_{6} \text { Debt }_{i, t}+\beta_{7} F C F_{i, t}+\beta_{8} \text { Dividend }_{i, t} \\
& +\beta_{9} \text { Age }_{i, t}+\text { Year }(\text { dum })+\operatorname{Industrial}(\text { dum })+\varepsilon_{i, t} \\
& O L S: Q_{i, t(t+1)}=\beta_{0}+\beta_{1} \widehat{I R E}_{i, t}+\beta_{2} S_{i z e_{i, t}}+\beta_{3} R O E_{i, t}+\beta_{4} D e b t_{i, t}+\beta_{5} F C F_{i, t} \\
& +\beta_{6} \text { Dividend }_{i, t}+\beta_{7} \text { Age }_{i, t}+\beta_{8} \text { Owner }_{i, t}+\beta_{9} \text { Audit }_{i, t} \\
& +\operatorname{Year}(\text { dum })+\operatorname{Industrial}(\text { dum })+\varepsilon_{i, t}
\end{aligned}
$$

본 연구는 소유지배괴리도와 기업의 비사업용부동산의 관계를 규명한 후 비사업용부동산과 기업가치와의 관계를 밝히고자 하였다. 소유지배괴리도와 기업의 비사업용부동산 간 회귀분석 에서는 총자산대비 비사업용부동산 비율을 종속변수로, 소유지배괴리도를 독립변수로 사용 하였다. 독립변수인 소유지배괴리도(Disparity)는 소유권과 지배권의 차이로, 매년 공정거래 위원회에서 발표하는 산정방법으로 측정하였다.10) 기업의 비사업용부동산과 기업가치 간의 관계를 실증하고자 토빈 $\mathrm{Q}$ 를 종속변수로 사용하고 소유지배괴리도와 기업의 비사업용부동산 간의 회귀분석에서 추정한 비사업용부동산 비율을 독립변수로 사용하였다. 토빈 $\mathrm{Q}$ 는 보통주의 시장가치와 우선주 장부가치 그리고 부채 장부가액을 총자산 장부가액으로 나누어 산출하였다.

기업의 비사업용부동산에 미치는 요인과 비사업용부동산이 기업가치에 미치는 요인은 소유지배괴리도 뿐만 아니라 당해 기업 고유의 특성과 재무적 요인이 영향을 미칠 수 있다. 이러한 점을 감안하여 기업규모(Size), 부채비율(Debt), 자기자본순이익률(ROE), 배당성향 (Dividend), 잉여현금흐름(FCF) 및 기업연령(Age)을 통제변수로 사용하였다. 기업의 부동산은 대체 투자수단임과 동시에 대리인 문제를 야기할 수 있는 요인으로서 기업규모(Asset)와 부채 비율(Debt)이 영향을 미칠 수 있다(Jensen, 1986; Stulz, 1990; Berger and Ofek, 1995; Yoon and Kim, 1999; Kwon and Park, 2007; Choi and Cho, 2012; Kwon, 2016). 이에 기업규모(Size)에 자연로그를 취한 값과 부채를 자본으로 나눈 부채비율(Debt)을 본 연구의 통제변수로 사용하였다. Abel and Blanchard(1986)와 Fazzari et al.(1987)은 기업의 투자결정요인으로 자기자본 순이익률, 배당성향 및 잉여현금흐름을 제시한 바, 본 연구에서도 이를 통제하였다. 자기자본순 이익률(ROE)는 당기순손익을 자기자본으로 나누어 산출하였으며, 배당성향(Divid)은 당기순이익 대비 총 배당금으로, 잉여현금흐름 $(\mathrm{FCF})$ 은 영업활동으로 인한 현금흐름을 매출액으로 나누어 측정하였다. 또한 기업 업력에 따라 사업다각화 및 대리인 문제가 발생할 수 있으므로(Anderson and Reeb, 2003) 업력(Age)을 통제변수로 사용하였다. 극단값으로 인한 실증결과의 왜곡을 막고자 통제변수들은 상하 $5 \%$ 에서 윈저라이징하였다. 또한 누락변수의 편향을 고려하여 연도와 산업을 통제하였다.

10) 소유지배괴리도(Disparity)는 지배권과 소유권의 차이로 계산한다. 소유권(Ownership)은 (동일인 지분+동일인의 친족지분)/(보통주 발행주식 수-자기주식 등), 그리고 지배권(Control)은 (동일인 지분+동일인의 친족지분+계열사 지분+임원지분+비영리법인지분)/(보통주 발행주식 수-자기주식 등)으로 계산한다. 
A Study of the Relationship between Corporate Governance and Non-business Real Estate

기업가치에 미치는 요인은 기업 고유의 특성 및 재무요인 뿐만 아니라 대형 감사인 여부와 지배주주 지분율도 영향을 미칠 수 있다. 대형 외부회계감사법인은 그렇지 않은 외감법인에 비해 높은 감사품질을 제공함으로서 기업 이익의 질을 높이고 이는 기업가치를 높인다는 연구결과(Choi and Lee, 2008)를 반영하여 대형 감사인11) 여부(Audit)를 비사업용부동산이 기업가치에 미치는 영향분석의 통제변수로 추가하였다. 또한 소유경영자는 지배주주 지분율이 높을수록 지배주주의 참호구축 현상(entrenchment)으로 인해 고위험 투자를 회피하게 되고 이로 인해 기업가치에 부정적인 영향을 미친다는 연구결과(Jung, 2015)를 감안하여 비사업용부동산이 기업가치에 미치는 영향분석의 통제변수로 지배주주지분율 (Owner)을 추가하였다.

본 연구는 기업의 비사업용부동산과 소유지배괴리도 간의 관계를 규명함과 동시에 두 변수의 관계에서 외부감시주체의 역할을 밝히고자 하였다. 특히 외국인투자자는 대리인 문제 최소화를 위해 경영감시에 노력을 기울이며(Ferreira and Matos, 2008; Aggarwal et al., 2011), 최적이 아닌 투자를 지양하도록 의사결정에 대한 감시역할을 수행한다(Mian and Nagata, 2015). 비사업용부동산이 대리인 비용을 야기하는 수단으로 작용한다면 외국인투자자는 이를 완화 시키거나 차단하는 역할을 할 것이다. 이에 $5 \%$ 이상 외국인투자자더미를 소유지배괴리도와의 상호작용 항으로 하여 조절변수로 사용하였다. 실증분석에 사용한 변수의 정의는 <표 $2>$ 에 제시하였다.

〈표 2〉 변수 정의

\begin{tabular}{|c|c|}
\hline 변수 & 정의 \\
\hline 기업가치(Tobin Q) & $\begin{array}{l}\text { (보통주 시장가치+우선주 장부가치+부채 장부가액)/총자산 } \\
\text { 장부가액 }\end{array}$ \\
\hline (IRE) & 총자산 대비 비사업용부동산 비율(비사업용부동산/총자산) \\
\hline 소유지 & 지배주주의 의결권과 소유권의 차이(의결권 \\
\hline $\begin{array}{l}\% \text { 이상 대량지분 외국인투자자(FOR) } \\
\text { 업규모(Size) }\end{array}$ & $\begin{array}{l}5 \% \text { 이상 대량지분 외국인투자자가 있으면 " } 1 \text { ", 없으면 “0" } \\
\text { 총 자산의 자연로그 값 }\end{array}$ \\
\hline & (부채 \\
\hline 률(ROE) & $\times 100$ \\
\hline & 00 \\
\hline F) & (영업 \\
\hline & 해당년도까지 년수의 자연로그 값 \\
\hline & 당해 연도말 기준 지배주주 1 인과 친족지분의 합 \\
\hline & 금감원 명시 4대 회계법인이면 “1”, 그렇지 않으면 “0” \\
\hline
\end{tabular}

11) 금융감독원에서는 매년 '회계법인 사업보고서 분석 및 시사점'에 대해 보고하고 있으며, 보고서에 '삼일, 삼정, 한영, 안진회계법인'을 4 대 회계법인으로 명시하고 있다. 따라서 본 연구의 통제변수로 사용한 대형 감사인 여부는 4 대 회계법인이 회계감사인이면 “1”을 그렇지 않으면 “0”의 더미변수로 설정하여 분석에 사용하였다. 


\section{4. 실증분석}

\section{1 기술통계량}

본 연구의 표본에 대한 기술통계량을 전체표본과 매출액 성장률 $20 \%$ 기준으로 고성장기업과 저성장기업으로 나누어 <표 3>에 제시하였다. 더불어 성장성기준, 부동산관련 여부, 대규모 기업집단 여부에 따른 주요변수의 평균값에 대한 $\mathrm{T}$-test 결과를 <표 $4>$ 에 제시하였다.

고성장기업은 저성장기업에 비해 토빈 $\mathrm{Q}$ 에서 0.403 만큼 $(\mathrm{p}<0.01)$ 높게, 비사업용부동산과 소유지배괴리도는 각각 $0.524(\mathrm{p}<0.05), 3.047$ 만큼 $(\mathrm{p}<0.01)$ 낮게 나타났다. 이러한 결과는, 고성장기업은 대체투자 수단으로서 비사업용부동산을 선택하려는 유인이 저성장기업에 비해 적을 수 있음을 암시한다 할 수 있다. 부동산 관련업종에서는 부동산관련 업종이 비관련 업종에 비해 토빈 Q가 0.595(p < 0.01)낮게 나타났으며, 비사업용부동산은 $1.725(\mathrm{p}<0.01$ )만큼 높게 나타났다. 그러나 소유지배괴리도는 통계적 유의성을 확인할 수 없었다. 대규모기업집단 여부로 나누어 T-test를 한 결과, 대규모기업집단이 비집단에 비해 토빈 $\mathrm{Q}$, 비사업용부동산, 소유지배 괴리도에서 각각 $0.222(\mathrm{p}<0.01), 0.849(\mathrm{p}<0.01), 1.438(\mathrm{p}<0.05)$ 낮게 나타났다.

\section{〈표 3〉 기술통계량}

\begin{tabular}{|c|c|c|c|c|c|c|c|c|c|c|c|c|c|c|c|}
\hline \multirow{2}{*}{ 변수명 } & \multicolumn{5}{|c|}{ 전체표본 } & \multicolumn{5}{|c|}{$\begin{array}{c}\text { 매출액 성장률 } 20 \% \text { 이상 기업 } \\
\text { (고성장기업) }\end{array}$} & \multicolumn{5}{|c|}{$\begin{array}{c}\text { 매출액 성장률 20\% 미만 기업 } \\
\text { (저성장기업) }\end{array}$} \\
\hline & Obs & Mean & $\begin{array}{l}\text { Std. } \\
\text { Dev. }\end{array}$ & Min & Max & Obs & Mean & $\begin{array}{l}\text { Std. } \\
\text { Dev. }\end{array}$ & Min & Max & Obs & Mean & $\begin{array}{l}\text { Std. } \\
\text { Dev. }\end{array}$ & Min & Max \\
\hline & 11,160 & & 1.292 & & 0 & 023 & 1.513 & 1.628 & & & 9,137 & 1.109 & 1.192 & 0.011 & 33.147 \\
\hline RE & 11,160 & 3.204 & 7.410 & 0.000 & 89.009 & 2,023 & 2.775 & 7.094 & 0.000 & 88.976 & 9,137 & 3.299 & 7.476 & 0.000 & 89.009 \\
\hline sparity & 11,160 & 12.001 & 16.314 & 0.000 & 85.750 & 2,023 & 9.506 & 15.0 & 0.000 & 82.190 & 9,137 & 12.553 & 16.5 & 0.000 & 85.750 \\
\hline ze & 11,160 & .071 & & 8. & 19 & 023 & 11.860 & & 8.869 & 19. & 9,137 & 12.117 & & 8.614 & 18.979 \\
\hline ebt & 11,160 & 81.956 & 69.562 & 8.390 & 265.280 & 2,023 & 80.128 & 68.167 & 8.390 & 265.280 & 9,137 & 82.361 & 69.865 & 8.390 & 265.280 \\
\hline $\mathrm{OE}$ & 11,160 & 5.800 & 11.284 & -21.110 & 26.480 & 2,023 & 10.176 & 11.705 & -21.110 & 26.480 & 9,137 & 4.831 & 10.956 & -21.110 & 26.480 \\
\hline vidend & 11,160 & 14.345 & 19.579 & 0.000 & 67.760 & 2,023 & 11.757 & 17.191 & 0.000 & 67.760 & 9,137 & 14.917 & 20.025 & 0.000 & 67.760 \\
\hline $\mathrm{CF}$ & 11,160 & 0.061 & 0.119 & -0.198 & 0.311 & 2,023 & 0.066 & 0.133 & -0.198 & 311 & 9,137 & 0.060 & 0.116 & -0.198 & 0.311 \\
\hline AGE & 11,160 & 3.135 & 0.721 & 0.000 & 4.787 & 2,023 & 3.010 & 0.631 & 0.693 & 54 & 9,137 & 3.163 & 0.737 & 0.000 & 4.787 \\
\hline Owner & 11,160 & 28.149 & 18.633 & 0.000 & 96.350 & 2,023 & 28.421 & 17.637 & 0.000 & 87.920 & 9,137 & 28.089 & 18.847 & 0.000 & 96.350 \\
\hline Audit & 11,160 & 0.528 & & & 1.0 & 2,023 & 0.480 & 0. & & & 9,137 & 0.539 & 0.4 & 0.000 & 1.000 \\
\hline Freigner & 11,160 & 0.104 & 0.305 & 0.000 & 1.000 & 2,023 & 0.094 & 0.292 & 0.000 & 1.000 & 9,137 & 0.106 & 0.308 & 0.000 & 1.000 \\
\hline
\end{tabular}

변수 간 상관관계에서 소유지배괴리도와 비사업용부동산 간 양(+)의 유의한 상관성을 보여 소유지배괴리도가 높을수록 비사업용부동산은 증가할 것이라는 가설 1 을 지지할 것으로 기대되며, 비사업용부동산과 기업가치 대용치인 토빈 $\mathrm{Q}$ 와의 유의한 음 $(-)$ 의 상관관계는 비사업용부동산이 증가할수록 기업가치는 하락할 것이라는 가설 3 을 지지할 것으로 예상된다. 또한 조절변수인 $5 \%$ 이상 외국인투자자와 비사업용부동산 간 음(-)의 상관관계가 나타나 소유지배괴리도와 비사업용부동산 간 외국인투자자의 모니터링 효과를 예상할 수 있다. 분산팽창계수(VIF)는 1.22 로 우려할 수준의 다중공선성 문제는 없는 것으로 확인되었다. 상관관계는 <표 $5>$ 와 같다. 
A Study of the Relationship between Corporate Governance and Non-business Real Estate

〈표 4〉 주요변수 평균차이 분석

이 표는 표본특성별 주요변수에 대한 평균값의 차이를 나타낸 것으로서 **** ***는 각각 $10 \%, 5 \%, 1 \%$ 의 신뢰수준에서 통계적으로 유의적임을 나타낸다.

Panel A: 성장성 기준

\begin{tabular}{lcccccccc}
\hline \multirow{2}{*}{ 변수명 } & \multicolumn{2}{c}{ 고성장 } & 기업 & & \multicolumn{2}{c}{ 저성장 기업 } & & \multicolumn{2}{c}{ 차이분석 } \\
\cline { 2 - 3 } \cline { 8 - 9 } & Obs & Mean & & Obs & Mean & & Diff. & t-value \\
\hline Q & 2,023 & 1.513 & & 9,137 & 1.11 & & $0.403^{* * *}$ & $(12.78)$ \\
IRE & 2,023 & 2.775 & & 9,137 & 3.299 & & $-0.524^{* *}$ & $(-2.87)$ \\
Disparity & 2,023 & 9.506 & & 9,137 & 12.553 & & $-3.047^{* * *}$ & $(-7.62)$ \\
\hline
\end{tabular}

Panel B: 부동산 관련

\begin{tabular}{|c|c|c|c|c|c|c|}
\hline \multirow{2}{*}{ 변수명 } & \multicolumn{2}{|c|}{ 부동산 관련업종 } & \multicolumn{2}{|c|}{ 부동산 비관련 업종 } & \multicolumn{2}{|c|}{ 차이분석 } \\
\hline & Obs & Mean & Obs & Mean & Diff. & t-value \\
\hline Q & 367 & 0.608 & 10,793 & 1.203 & $-0.595^{* * *}$ & $(-8.70)$ \\
\hline IRE & 367 & 4.872 & 10,793 & 3.147 & $1.725^{* * *}$ & (4.39) \\
\hline Disparity & 367 & 11.627 & 10,793 & 12.013 & -0.386 & $(-0.45)$ \\
\hline
\end{tabular}

Panel C: 대규모 기업집단 여부

\begin{tabular}{|c|c|c|c|c|c|c|}
\hline \multirow{2}{*}{ 변수명 } & \multicolumn{2}{|c|}{ 대규모 기업집단 } & \multicolumn{2}{|c|}{ 비 기업집단 } & \multicolumn{2}{|c|}{ 차이분석 } \\
\hline & Obs & Mean & Obs & Mean & Diff. & t-value \\
\hline $\mathrm{Q}$ & 1,404 & 0.989 & 9,756 & 1.211 & $-0.222^{* * * *}$ & $(-6.03)$ \\
\hline IRE & 1,404 & 2.462 & 9,756 & 3.311 & $-0.849^{* * *}$ & $(-4.01)$ \\
\hline Disparity & 1,404 & 10.744 & 9,756 & 12.182 & $-1.438^{* *}$ & $(-3.09)$ \\
\hline
\end{tabular}

〈표 5〉상관관계표

표는 본 연구에 사용한 종속변수, 독립변수, 통제변수 및 조절변수에 대한 상관계수를 나타내며, *, **, ***는 각각 $10 \%, 5 \%, 1 \%$ 의 신뢰수준에서 통계적으로 유의적임을 나타낸다.

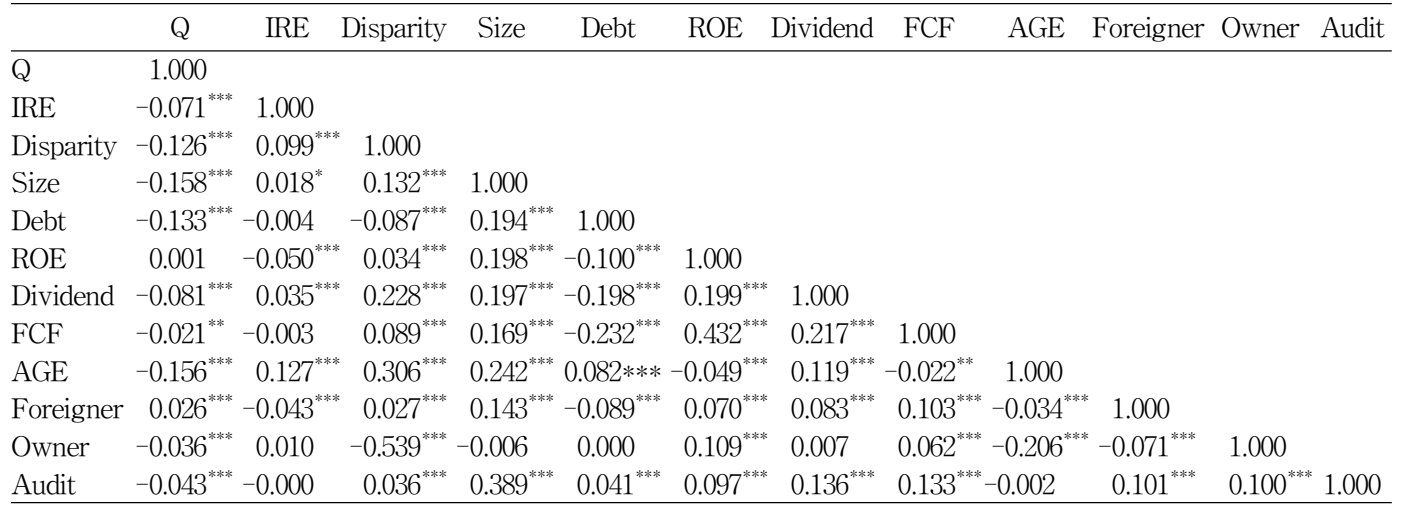

\section{2 실증결과}

가설 1 의 실증을 위해 종속변수로 비사업용부동산비율을, 독립변수로 소유지배괴리도를 설정하였다. 비사업용부동산비율은 중도절단된 자료의 특성을 고려하여 토빗 회귀분석을 시행 
한국증권학회지 제 50 권 3호 (2021)

하였다. 소유지배괴리도가 당기의 비사업용부동산비율에 영향을 미칠 수도 있지만, 당기의 소유지배괴리도가 시차를 두고 비사업용부동산에 작용할 수 있다. 이에 당기 비사업용부동산 비율에 대한 소유지배괴리도의 영향과 함께 1 기간 후 시차변수를 종속변수로 사용하였다. 가설 1 의 소유지배괴리도가 비사업용부동산에 미치는 영향에 대한 결과는 <표 6>에 제시하였다.

〈표 6〉소유지배괴리도가 비사업용부동산에 미치는 영향

<표 6>은 소유지배괴리도가 당기의 비사업용부동산에 미치는 영향을 분석한 표로서, 총자산대비 비사업용 부동산 비율(IRE)을 종속변수로, 소유권과 지배권의 차이인 소유지배괴리도(Disparity)를 독립변수로 하고, 총자산의 자연로그값(Size), 자기자본이익률[(ROE: (당기순이익/자기자본)×100], 부채비율[(Debt: (부채/자본×100)], 잉여현금흐름[FCF: (영업현금흐름/매출액)×100)], 배당성향[(Dividend: (총배당금/ 당기순이익 $\times 100$ ] 및 설립부터 해당년도까지 년수의 자연로그값을 사용한 업력(Age)과 연도와 산업더미를 통제변수로 사용하여 토빗회귀분석을 시행한 결과로 *, ${ }^{* *},{ }^{* * *}$ 는 각각 $10 \%, 5 \%, 1 \%$ 의 신뢰수준에서 통계적으로 유의적임을 나타내며, 괄호안의 값은 표준오차를 의미한다.

\begin{tabular}{|c|c|c|c|c|c|c|c|}
\hline $\begin{array}{l}\text { [De.Var. } \\
\text { IRE] }\end{array}$ & $\begin{array}{l}\text { 전체 } \\
\text { 표본 }\end{array}$ & $\begin{array}{l}\text { 고성장 } \\
\text { 기업 }\end{array}$ & $\begin{array}{l}\text { 저성장 } \\
\text { 기업 }\end{array}$ & $\begin{array}{l}\text { 부동산 } \\
\text { 관련업 }\end{array}$ & $\begin{array}{c}\text { 부동산 } \\
\text { 비관련업 }\end{array}$ & $\begin{array}{c}\text { 대규모 } \\
\text { 기업집단 }\end{array}$ & 비 기업집단 \\
\hline \multirow[t]{2}{*}{ Disparity } & $0.029^{* * *}$ & 0.015 & $0.032^{* * *}$ & $0.073^{* * *}$ & $0.028^{* * *}$ & $0.038^{* * *}$ & $0.023^{* * *}$ \\
\hline & $(0.005)$ & $(0.011)$ & $(0.005)$ & $(0.026)$ & $(0.005)$ & $(0.009)$ & $(0.005)$ \\
\hline \multirow[t]{2}{*}{ Size } & -0.052 & -0.081 & -0.049 & $-0.485^{*}$ & -0.062 & $-0.278^{* * *}$ & $0.346^{* * *}$ \\
\hline & $(0.055)$ & $(0.138)$ & $(0.060)$ & $(0.268)$ & $(0.056)$ & $(0.085)$ & $(0.083)$ \\
\hline \multirow[t]{2}{*}{ ROE } & $-0.036^{* * *}$ & $-0.056^{* * *}$ & $-0.030^{* * *}$ & $-0.116^{* * *}$ & $-0.032^{* * *}$ & $-0.043^{* * *}$ & $-0.041^{* * *}$ \\
\hline & $(0.007)$ & $(0.015)$ & $(0.008)$ & $(0.029)$ & $(0.007)$ & $(0.015)$ & $(0.008)$ \\
\hline \multirow[t]{2}{*}{ Debt } & -0.000 & 0.001 & -0.000 & $0.011^{* *}$ & -0.001 & 0.001 & -0.001 \\
\hline & $(0.001)$ & $(0.002)$ & $(0.001)$ & $(0.005)$ & $(0.001)$ & $(0.002)$ & $(0.001)$ \\
\hline \multirow[t]{2}{*}{ FCF } & 0.887 & 1.979 & 0.629 & -5.277 & 1.006 & $-3.745^{* *}$ & $1.265^{*}$ \\
\hline & $(0.668)$ & (1.340) & $(0.764)$ & (3.246) & $(0.681)$ & (1.453) & $(0.731)$ \\
\hline \multirow[t]{2}{*}{ Dividend } & $0.006^{*}$ & 0.005 & 0.006 & -0.004 & $0.007^{*}$ & 0.007 & 0.005 \\
\hline & $(0.004)$ & $(0.010)$ & $(0.004)$ & $(0.022)$ & $(0.004)$ & $(0.007)$ & $(0.004)$ \\
\hline \multirow[t]{2}{*}{ AGE } & $1.084^{* * *}$ & $1.614^{* * *}$ & $0.989^{* * *}$ & $-1.818^{* * *}$ & $1.119^{* * * *}$ & $0.473^{* * *}$ & $1.157^{* * *}$ \\
\hline & $(0.104)$ & $(0.266)$ & $(0.114)$ & $(0.679)$ & $(0.106)$ & (0.183) & (0.118) \\
\hline $\begin{array}{l}\text { Industrial } \\
\text { Year }\end{array}$ & & & & Included & & & \\
\hline $\mathrm{N}$ & 11,160 & 2,023 & 9,137 & 367 & 10,793 & 1,404 & 9,756 \\
\hline pseudo $\mathrm{R}-\mathrm{sq}$ & 0.003 & 0.005 & 0.003 & 0.020 & 0.003 & 0.008 & 0.004 \\
\hline
\end{tabular}

<표 6>에서 전체 표본을 대상으로 실증 분석한 결과, 소유지배괴리도는 비사업용부동산과 유의한 양(+)의 관계가 나타나 소유지배괴리도가 클수록 비사업용부동산이 증가한다는 가설 1 을 지지하였다. 이러한 양(+)의 관계는 부동산 관련·비관련업종, 대규모기업집단·비집단에서 모두 일관되게 나타났다. 즉 소유지배괴리도가 증가할수록 비사업용부동산이 증가하는데, 이는 부동산 관련업종 및 대규모기업집단여부에 따라 차별적이지 않음을 의미하는 것으로 가설 1-2와 1-3을 기각시키는 결과라 할 수 있다.12) 그러나 성장성여부에 따른 분석에서 고성장기업은

$12)$ 소유지배괴리도와 비사업용부동산 모두 양수인 기업만 $(\mathrm{n}=3,721)$ 을 대상으로 소유지배괴리도가 
A Study of the Relationship between Corporate Governance and Non-business Real Estate

소유지배괴리도와 비사업용부동산 간에 유의적이지 않았으나, 저성장기업은 소유지배괴리도와 비사업용부동산 간 양 $(+)$ 의 관계가 나타나 가설 1-1을 지지하였다. 이러한 결과는 고성장기업의 경우 본업이 비사업용부동산에 비해 더 큰 수익을 가져다 줄 것이기 때문에 비사업용부동산 투자 및 보유에 대한 경영자의 유인이 적은 것으로 해석할 수 있는데 반해, 저성장기업의 경우 경영자는 대체투자 자원이든 사적이익 수단이든 비사업용부동산에 대한 활용유인이 존재한다고 할 수 있다. 이러한 결과는 1 기간 후의 비사업용부동산 비율을 종속변수로 사용한 회귀분석에서도

〈표 7〉 소유지배괴리도가 1기간 후 비사업용부동산에 미치는 영향

<표 7>은 소유지배괴리도가 1기간 후의 비사업용부동산에 미치는 영향을 분석한 표로서, 총자산대비 비사업용부동산 비율(IRE)을 종속변수로, 소유권과 지배권의 차이인 소유지배괴리도(Disparity)를 독립 변수로 하고, 총자산의 자연로그값(Size), 자기자본이익률[(ROE: (당기순이익/자기자본)×100], 부채비율 [(Debt: (부채/자본×100)],잉여현금흐름[FCF: (영업현금흐름/매출액)×100)], 배당성향[(Dividend: (총배당금/ 당기순이익)×100] 및 설립부터 해당년도까지 년수의 자연로그값을 사용한 업력(Age)과 연도와 산업더미를 통제변수로 사용하여 토빗회귀분석을 시행한 결과로, ${ }^{*},{ }^{* *},{ }^{* * *}$ 는 각각 $10 \%, 5 \%, 1 \%$ 의 신뢰수준에서 통계적으로 유의적임을 나타내며, 괄호안의 값은 표준오차를 의미한다.

\begin{tabular}{lccccccc}
\hline \multicolumn{1}{c}{$\begin{array}{c}\text { [De.Var. } \\
\text { IRE t+1] }\end{array}$} & $\begin{array}{c}\text { 전체 } \\
\text { 표본 }\end{array}$ & $\begin{array}{c}\text { 고성장 } \\
\text { 기업 }\end{array}$ & $\begin{array}{c}\text { 저성장 } \\
\text { 기업 }\end{array}$ & $\begin{array}{c}\text { 부동산 } \\
\text { 관련업 }\end{array}$ & $\begin{array}{c}\text { 부동산 } \\
\text { 비관련업 }\end{array}$ & $\begin{array}{c}\text { 대규모 } \\
\text { 기업집단 }\end{array}$ & 비 기업집단 \\
\hline Disparity & $0.028^{* * *}$ & 0.010 & $0.030^{* * *}$ & $0.051^{*}$ & $0.027^{* * *}$ & $0.035^{* * *}$ & $0.021^{* * *}$ \\
& $(0.005)$ & $(0.013)$ & $(0.006)$ & $(0.028)$ & $(0.005)$ & $(0.009)$ & $(0.006)$ \\
Size & -0.036 & -0.008 & -0.038 & -0.417 & -0.041 & $-0.314^{* * *}$ & $0.391^{* * *}$ \\
& $(0.061)$ & $(0.160)$ & $(0.066)$ & $(0.288)$ & $(0.063)$ & $(0.093)$ & $(0.093)$ \\
ROE & $-0.041^{* * *}$ & $-0.056^{* * *}$ & $-0.036^{* * *}$ & $-0.089^{* * *}$ & $-0.037^{* * *}$ & $-0.046^{* * *}$ & $-0.046^{* * *}$ \\
& $(0.008)$ & $(0.017)$ & $(0.009)$ & $(0.033)$ & $(0.008)$ & $(0.016)$ & $(0.008)$ \\
Debt & -0.001 & 0.002 & -0.002 & 0.007 & $-0.002^{*}$ & 0.000 & $-0.002^{*}$ \\
& $(0.001)$ & $(0.003)$ & $(0.001)$ & $(0.006)$ & $(0.001)$ & $(0.002)$ & $(0.001)$ \\
FCF & 0.436 & $2.655^{*}$ & -0.099 & -0.396 & 0.431 & $-4.056^{* *}$ & 0.801 \\
& $(0.754)$ & $(1.526)$ & $(0.857)$ & $(3.572)$ & $(0.771)$ & $(1.637)$ & $(0.826)$ \\
Dividend & 0.006 & 0.006 & 0.006 & -0.003 & 0.007 & 0.011 & 0.004 \\
& $(0.004)$ & $(0.011)$ & $(0.005)$ & $(0.024)$ & $(0.004)$ & $(0.008)$ & $(0.005)$ \\
AGE & $0.991^{* * *}$ & $1.548^{* * *}$ & $0.895^{* * *}$ & $-1.869^{* *}$ & $1.025^{* * *}$ & $0.475^{* *}$ & $1.051^{* * *}$ \\
& $(0.117)$ & $(0.308)$ & $(0.127)$ & $(0.762)$ & $(0.119)$ & $(0.200)$ & $(0.133)$ \\
Industrial & & & & Included & & & \\
Year & & & & & & \\
N & 9,337 & 1,625 & 7,712 & 310 & 9,027 & 1,176 & 8,161 \\
pseudo R-sq & 0.003 & 0.004 & 0.003 & 0.011 & 0.003 & 0.008 & 0.003 \\
\hline
\end{tabular}

비사업용부동산에 미치는 영향을 회귀분석 하였으며, 상장요건을 감안하여 유가증권상장시장 기업 $(\mathrm{n}$ $=1,979)$ 과 코스닥 상장기업 $(\mathrm{n}=1,742)$ 을 나누어 회귀분석 하였다. 분석 결과, 회귀계수와 유의수준에 차이가 있을 뿐 일관되게 양 $(+)$ 의 관계 즉, 소유지배괴리도가 클수록 비사업용부동산이 증가한다는 일관된 결과를 확인하였다. 유가증권상장기업 $(\beta=0.053, \mathrm{p}<0.01)$ 과 코스닥 상장기업 $(\beta=0.065$, $\mathrm{p}<0.01)$ 을 나누어 분석한 결과에서도 두 집단 모두 양 $(+)$ 의 유의한 결과가 나타났다. 또한 소유지배 괴리도가 1 기간 후 비사업용부동산 $(\mathrm{n}=3,151)$ 에 미치는 영향을 분석한 결과에서도 일관된 결과를 보였다. 지면관계상 분석결과는 생략하였다. 
한국증권학회지 제 50 권 3호 (2021)

일관되게 나타남으로써 성장성여부를 제외한 부동산 관련업종 및 대규모기업집단여부와 관계없이 소유지배괴리도가 클수록 비사업용부동산이 증가한다는 것을 강하게 지지한다고 할 수 있다. 소유지배괴리도가 1 기간 후 비사업용부동산에 미치는 영향에 대한 회귀결과는 <표 $7>$ 과 같다.

기업은 비사업용 자산을 보유 또는 비사업용 자산에 투자함으로써 기회손실을 야기할 수 있다. 다시 말해 기업은 사업용자산 발생현금흐름이 비사업용자산 발생현금흐름보다 많음에도 불구하고 비사업용자산을 보유·투자 한다면 손실을 발생시킬 수 있음을 의미하며, 이는 주주가치 저하로 이어질 수 있다. 특히 경영자는 소유지배괴리의 차이에 따라 투자의사결정 과정에서 정보우위를 활용하여 경영자 본인의 사적이익을 위해 비생산적 투자를 감행하여 대리인문제를 발생시킬 수도 있다. 따라서 기업의 잘못된 투자결정에 대해 주주의 철저한 감시와 견제가

〈표 8〉 외국인투자자의 소유지배괴리도와 비사업용부동산 간 조절효과: 성장성 기준 <표 8>은 소유지배괴리도와 당기의 비사업용부동산과의 관계에서 기업의 성장성 여부에 따른 외국인 투자자의 조절효과를 분석한 것으로, 총자산대비 비사업용부동산 비율(IRE)을 종속변수로, 소유권과 지배권의 차이인 소유지배괴리도(Disparity)를 독립변수로 하고, $5 \%$ 이상 대량지분 외국인투자자(Foreign)를 더미변수로 하여 조절변수로 사용하였으며, 총자산의 자연로그값(Size), 자기자본이익률[(ROE: (당기 순이익/자기자본 $\times 100]$, 부채비율[(Debt: (부채/자본×100)], 잉여현금흐름[FCF: (영업현금흐름/매출액) $\times 100$ )], 배당성향[(Dividend: (총배당금/당기순이익)×100] 및 설립부터 해당년도까지 년수의 자연로그값을 사용한 업력(Age)과 연도와 산업더미를 통제변수로 사용하여 토빗회귀분석을 시행한 결과로, ${ }^{*},{ }^{* * *},{ }^{* * *}$ 는 각각 $10 \%, 5 \%, 1 \%$ 의 신뢰수준에서 통계적으로 유의적임을 나타내며, 괄호안의 값은 표준오차를 의미한다.

\begin{tabular}{|c|c|c|c|c|c|c|}
\hline \multirow{2}{*}{$\frac{\text { [de.var: IRE] }}{\text { Disparity (A) }}$} & \multicolumn{2}{|c|}{ 전체표본 } & \multicolumn{2}{|c|}{ 고성장 기업 } & \multicolumn{2}{|c|}{ 저성장 기업 } \\
\hline & $0.029^{* * * *}$ & $0.034^{* * * *}$ & 0.015 & 0.018 & $0.032^{* * *}$ & $0.037^{* * *}$ \\
\hline & $(0.005)$ & $(0.005)$ & $(0.011)$ & $(0.012)$ & $(0.005)$ & $(0.005)$ \\
\hline \multirow[t]{2}{*}{ Foreign (B) } & $-0.979^{* * *}$ & -0.407 & -0.043 & 0.313 & $-1.180^{* * *}$ & $-0.582^{*}$ \\
\hline & $(0.232)$ & $(0.293)$ & $(0.538)$ & $(0.649)$ & $(0.257)$ & (0.328) \\
\hline \multirow[t]{2}{*}{$(\mathrm{A}) \times(\mathrm{B})$} & & $-0.043^{* * *}$ & & -0.038 & & $-0.042^{* * *}$ \\
\hline & & $(0.013)$ & & $(0.038)$ & & $(0.014)$ \\
\hline \multirow{2}{*}{ Size } & -0.016 & -0.021 & -0.080 & -0.086 & -0.004 & -0.009 \\
\hline & $(0.055)$ & $(0.055)$ & (0.138) & (0.138) & $(0.061)$ & $(0.061)$ \\
\hline \multirow[t]{2}{*}{$\mathrm{ROE}$} & $-0.036^{* * *}$ & $-0.037^{* * *}$ & $-0.056^{* * *}$ & $-0.056^{* * *}$ & $-0.030^{* * *}$ & $-0.031^{* * *}$ \\
\hline & $(0.007)$ & $(0.007)$ & $(0.015)$ & $(0.015)$ & $(0.008)$ & (0.008) \\
\hline \multirow[t]{2}{*}{ Debt } & -0.001 & -0.001 & 0.001 & 0.001 & -0.001 & -0.001 \\
\hline & $(0.001)$ & $(0.001)$ & $(0.002)$ & $(0.002)$ & $(0.001)$ & $(0.001)$ \\
\hline \multirow[t]{2}{*}{$\mathrm{FCF}$} & 0.996 & 0.990 & 1.982 & 2.022 & 0.774 & 0.759 \\
\hline & $(0.668)$ & (0.667) & (1.341) & (1.341) & $(0.763)$ & $(0.763)$ \\
\hline \multirow[t]{2}{*}{ Dividend } & $0.007^{*}$ & $0.007^{*}$ & 0.005 & 0.005 & 0.007 & 0.007 \\
\hline & $(0.004)$ & $(0.004)$ & $(0.010)$ & $(0.010)$ & $(0.004)$ & $(0.004)$ \\
\hline \multirow[t]{2}{*}{ AGE } & $1.055^{* * *}$ & $1.059^{* * * *}$ & $1.613^{* * * *}$ & $1.623^{* * *}$ & $0.951^{* * *}$ & $0.954^{* * *}$ \\
\hline & $(0.104)$ & $(0.104)$ & $(0.266)$ & $(0.266)$ & $(0.114)$ & (0.114) \\
\hline $\begin{array}{l}\text { Industrial } \\
\text { Year }\end{array}$ & Included & & & & & \\
\hline $\mathrm{N}$ & 11,160 & 11,160 & 2,023 & 2,023 & 9,137 & 9,137 \\
\hline pseudo $\mathrm{R}^{-} \mathrm{sq}$ & 0.004 & 0.004 & 0.005 & 0.005 & 0.003 & 0.004 \\
\hline
\end{tabular}


A Study of the Relationship between Corporate Governance and Non-business Real Estate

요구된다. 외부감시주체로서 외국인투자자는 개인이나 다른 기관 투자자에 비해 적극적인 모니터링 활동으로 대리인문제를 완화시키는 역할(Park and Lee, 2006; Kim et al., 2010; Jeon and Moffett, 2010)을 수행하고, 기업가치 제고를 견인한다(Park et al., 2004; He and Shen, 2014). 이러한 외국인투자자의 감시효과를 전제로 소유지배괴리도와 비사업용부동산 간 외국인투자자의 역할을 조명하였다.

전체 표본을 대상으로 분석한 결과, $5 \%$ 이상 대량지분 13$)$ 보유 외국인투자자가 있는 기업에서는 소유지배괴리도와 비사업용부동산비율 간 양 $(+)$ 의 관계가 유의하게 완화(-)됨을 확인하였다. 성장성을 기준으로 표본을 나누어 분석한 결과, 특히 저성장기업에서 일관된 음(-)의 유의적인 조절효과를 보임으로써 소유지배괴리도와 비사업용부동산 간의 양(+)의 관계를 완화시키는 것으로 확인되었다. 고성장기업은 <표 $6>$ 과 <표 $7>$ 의 결과와 같은 맥락에서 소유지배괴리도의 수준과 관계없이 비사업용부동산에 대한 유인이 크지 않고, 이에 따라 외국인투자자의 견제유인이 없다고 할 수 있다. 이에 대한 분석결과는 <표 8>에 정리하였다.

<표 9>는 부동산 관련업종 여부와 대규모 기업집단 여부에 따른 외국인투자자의 조절효과를 분석한 결과이다. 부동산 관련업에 따른 결과에서 부동산 비관련업에 대해 외국인투자자는 소유지배괴리도 증가에 따른 비사업용부동산 증가의 영향을 완화(-)시키는 결과를 보여, 외국인 투자자의 견제효과를 확인할 수 있었다. 이에 반해 부동산 관련업종에서는 유의성이 없는 것으로 나타났다. 이러한 결과는 부동산 자체가 부동산 관련업의 목적사업이므로 외국인투자자의 모니터링이 불필요하기 때문인 것으로 해석된다.

대규모기업집단 여부에 따른 분석결과, 대규모기업집단 소속기업에서는 유의적이지 않은 것으로 나타났고, 비집단 기업에서는 유의한 음(-)의 조절효과가 확인되었다. 이는 대규모기업 집단 소속기업에 비해 비집단 기업의 경우 외국인투자자의 감시효과가 더욱 효과적임을 시사한다.

1 기간 후의 비사업용부동산비율을 종속변수로 사용한 실증분석 결과에서도 저성장기업, 부동산 비관련업종 및 비집단 기업에서 외국인투자자는 소유지배괴리도와 비사업용부동산 간 양(+)의 영향을 완화시킴으로써 외부감시주체로서의 기능을 한다고 할 수 있다. 그러나 고성장 기업, 부동산관련업 그리고 대규모기업집단 소속기업에서는 외국인투자자의 조절효과가 나타 나지 않았다. 이에 대한 결과는 <표 10>과 <표 11>에 정리하였으며, 외국인투자자의 조절효과는 <그림 1>과 <그림 2>에 제시하였다.

13) $5 \%$ 이상 대량 지분 외국인투자자의 지분율을 조절변수로 사용하였을 때에도 고성장기업, 부동산 관련업종, 대규모기업집단에서는 외국인투자자의 조절효과는 통계적으로 유의적이지 않았으나, 저성장기업 $(\beta=-0.029, \mathrm{p}<0.01)$, 부동산 비관련업종 $(\beta=-0.035, \mathrm{p}<0.01)$ 및 비 기업집단 $(\beta=-0.038$, $\mathrm{p}<0.01)$ 에서는 외국인투자자가 소유지배괴리도의 증가에 따른 비사업용부동산 증가를 완화 시키는 것으로 더미변수를 사용했을 때와 일관된 조절효과가 확인되었다. 더불어 유가증권시장 상장기업( $\beta$ $=-0.026, \mathrm{p}<0.05)$ 에서는 외국인투자자의 조절효과가 나타난 반면 코스닥 상장기업에서는 유의적 이지 않았다. 이는 고성장기업 표본 2,023개 중 코스닥 상장기업이 $73.65 \%, 1,490$ 개로 고성장기업의 대다수가 코스닥 상장기업에 기인한 것으로 해석된다. 또한 소유지배괴리도와 비사업용부동산 모두 양수인 기업만 $(\mathrm{n}=3,721)$ 을 대상으로 외국인투자자의 조절효과를 실증 분석한 결과 역시 일관되게 나타남으로써 가설 2 를 강건하게 지지한다고 할 수 있다. 
한국증권학회지 제 50 권 3호 (2021)

〈표 9〉외국인투자자의 소유지배괴리도와 비사업용부동산 간 조절효과: 부동산 관련 및 기업집단 여부

<표 9>는 소유지배괴리도와 당기의 비사업용부동산과의 관계에서 업종 및 기업집단 여부에 따른 외국인 투자자의 조절효과를 분석한 것으로, 총자산대비 비사업용부동산 비율(IRE)을 종속변수로, 소유권과 지배권의 차이인 소유지배괴리도(Disparity)를 독립변수로 하고, $5 \%$ 이상 대량지분 외국인투자자(Foreign)를 더미변수로 하여 조절변수로 사용하였으며, 총자산의 자연로그값(Size), 자기자본이익률 $[\mathrm{ROE}$ : (당기 순이익/자기자본 $\times 100]$, 부채비율[(Debt: (부채/자본×100)], 잉여현금흐름[FCF: (영업현금흐름/매출액) $\times 100)$ ], 배당성향[(Dividend: (총배당금/당기순이익)×100] 및 설립부터 해당년도까지 년수의 자연로그값을 사용한 업력(Age)과 연도와 산업더미를 통제변수로 사용하여 토빗회귀분석을 시행한 결과로, *, **, ${ }^{* * *}$ 는 각각 $10 \%, 5 \%, 1 \%$ 의 신뢰수준에서 통계적으로 유의적임을 나타내며, 괄호안의 값은 표준오차를 의미한다.

\begin{tabular}{|c|c|c|c|c|c|c|c|c|}
\hline \multirow{2}{*}{$\frac{\text { [de.var: IRE] }}{\text { Disparity (A) }}$} & \multicolumn{2}{|c|}{ 부동산 관련 } & \multicolumn{2}{|c|}{ 부동산 비관련 } & \multicolumn{2}{|c|}{ 대규모기업집단 } & \multicolumn{2}{|c|}{ 비 기업집단 } \\
\hline & $0.073^{* * *}$ & $0.085^{* * *}$ & $0.028^{* * * *}$ & $0.033^{* * *}$ & $0.038^{* * *}$ & $0.040^{* * *}$ & $0.023^{* * * *}$ & $0.028^{* * * *}$ \\
\hline & $(0.026)$ & $(0.028)$ & $(0.005)$ & $(0.005)$ & $(0.009)$ & $(0.009)$ & $(0.005)$ & $(0.005)$ \\
\hline \multirow[t]{2}{*}{ Foreign (B) } & 0.110 & 1.907 & $-1.008^{* * *}$ & -0.442 & -0.329 & -0.148 & $-1.212^{* * * *}$ & -0.549 \\
\hline & (1.325) & (1.946) & $(0.235)$ & $(0.296)$ & (0.405) & $(0.482)$ & $(0.262)$ & $(0.334)$ \\
\hline \multirow[t]{2}{*}{$(\mathrm{A}) \times(\mathrm{B})$} & & -0.118 & & $-0.043^{* * *}$ & & -0.018 & & $-0.047^{* * *}$ \\
\hline & & $(0.094)$ & & $(0.014)$ & & $(0.026)$ & & (0.015) \\
\hline \multirow[t]{2}{*}{ Size } & $-0.485^{*}$ & $-0.461^{*}$ & -0.024 & -0.030 & $-0.268^{* * *}$ & $-0.270^{* * *}$ & $0.407^{* * * *}$ & $0.403^{* * *}$ \\
\hline & $(0.268)$ & $(0.268)$ & $(0.057)$ & $(0.057)$ & $(0.086)$ & $(0.086)$ & $(0.084)$ & $(0.084)$ \\
\hline \multirow[t]{2}{*}{ ROE } & $-0.116^{* * *}$ & $-0.114^{* * *}$ & $-0.032^{* * *}$ & $-0.033^{* * *}$ & $-0.044^{* * *}$ & $-0.044^{* * *}$ & $-0.041^{* * *}$ & $-0.042^{* * * *}$ \\
\hline & (0.029) & $(0.029)$ & $(0.007)$ & $(0.007)$ & $(0.015)$ & $(0.015)$ & $(0.008)$ & (0.008) \\
\hline \multirow[t]{2}{*}{ Debt } & $0.011^{* *}$ & $0.012^{* *}$ & $-0.002^{*}$ & $-0.002^{*}$ & 0.001 & 0.001 & -0.002 & -0.002 \\
\hline & $(0.005)$ & $(0.005)$ & $(0.001)$ & $(0.001)$ & $(0.002)$ & $(0.002)$ & $(0.001)$ & $(0.001)$ \\
\hline \multirow[t]{2}{*}{ FCF } & -5.288 & $-5.384^{*}$ & 1.116 & 1.112 & $-3.626^{* *}$ & $-3.670^{* *}$ & $1.360^{*}$ & $1.375^{*}$ \\
\hline & (3.249) & (3.243) & $(0.681)$ & $(0.680)$ & (1.460) & (1.461) & $(0.730)$ & $(0.730)$ \\
\hline \multirow[t]{2}{*}{ Dividend } & -0.005 & -0.008 & $0.007^{*}$ & $0.007^{*}$ & 0.007 & 0.007 & 0.005 & 0.005 \\
\hline & $(0.022)$ & $(0.022)$ & $(0.004)$ & $(0.004)$ & $(0.007)$ & $(0.007)$ & $(0.004)$ & $(0.004)$ \\
\hline \multirow[t]{2}{*}{ AGE } & $-1.819^{* * *}$ & $-1.870^{* * *}$ & $1.088^{* * *}$ & $1.093^{* * *}$ & $0.460^{* *}$ & $0.462^{* *}$ & $1.121^{* * *}$ & $1.124^{* * *}$ \\
\hline & (0.679) & (0.678) & $(0.106)$ & $(0.106)$ & (0.183) & (0.183) & (0.118) & (0.118) \\
\hline $\begin{array}{l}\text { Industrial } \\
\text { Year }\end{array}$ & \multicolumn{8}{|c|}{ Included } \\
\hline $\mathrm{N}$ & 367 & 367 & 10,793 & 10,793 & 1,404 & 1,404 & 9,756 & 9,756 \\
\hline pseudo R-sq & 0.020 & 0.021 & 0.004 & 0.004 & 0.008 & 0.008 & 0.004 & 0.004 \\
\hline
\end{tabular}

비사업용부동산이 기업의 대체투자 수단으로서 이용된다면 기업가치 제고로 이어질 것이나, 기업가치를 저해하는 기업의 비생산적 자원이라면 과잉투자에 따른 결과 내지는 터널링의 수단으로 의심할 수 있고, 따라서 대리인 문제로 이어질 수 있다. 이에 본 연구에서는 소유지배 괴리도와 비사업용부동산비율과의 토빗모형으로 추정한 비사업용부동산비율을 독립변수로 설정하여 기업의 비사업용부동산이 기업가치에 미치는 영향을 분석, 비사업용부동산이 대체투자 수단인지, 대리인문제의 원인으로 작용할 수 있는지를 조명하였다. 비사업용부동산이 유효한 대체투자 수단이라면 기업가치에 유의적인 양 $(+)$ 의 회귀계수가 나타날 것이고, 대리인문제의 한 원인으로서 작용한다면 음(-)의 회귀계수가 제시될 것이다. 
A Study of the Relationship between Corporate Governance and Non-business Real Estate

〈표 10〉소유지배괴리도와 1기간 후 비사업용부동산 간 외국인투자자의 조절효과: 성장성기준 <표 10>은 소유지배괴리도와 1 기간 후 비사업용부동산과의 관계에서 기업의 성장성 여부에 따른 외국인투자자의 조절효과를 분석한 것으로, 총자산대비 비사업용부동산 비율(IRE)을 종속변수로, 소유권과 지배권의 차이인 소유지배괴리도(Disparity)를 독립변수로 하고, $5 \%$ 이상 대량지분 외국인투자자(Foreign)를 더미변수로 하여 조절변수로 사용하였으며, 총자산의 자연로그값(Size), 자기자본이익률[(ROE: (당기 순이익/자기자본 $\times 100]$, 부채비율[(Debt: (부채/자본×100)], 잉여현금흐름[FCF: (영업현금흐름/매출액) $\times 100)]$, 배당성향[(Dividend:(총배당금/당기순이익)×100] 및 설립부터 해당년도까지 년수의 자연로그값을 사용한 업력(Age)과 연도와 산업더미를 통제변수로 사용하여 토빗회귀분석을 시행한 결과로 *, ${ }^{* *},{ }^{* * *}$ 는 각각 $10 \%, 5 \%, 1 \%$ 의 신뢰수준에서 통계적으로 유의적임을 나타내며, 괄호안의 값은 표준오차를 의미한다.

\begin{tabular}{|c|c|c|c|c|c|c|}
\hline \multirow{2}{*}{$\frac{\text { [ de.var: IRE } \mathrm{t}+1]}{\text { Disparity }(\mathrm{A})}$} & \multicolumn{2}{|c|}{ 전체표본 } & \multicolumn{2}{|c|}{ 고성장기업 } & \multicolumn{2}{|c|}{ 저성장기업 } \\
\hline & $0.028^{* * *}$ & $0.032^{* * *}$ & 0.010 & 0.011 & $0.031^{* * *}$ & $0.036^{* * *}$ \\
\hline & $(0.005)$ & $(0.005)$ & $(0.013)$ & $(0.013)$ & $(0.006)$ & $(0.006)$ \\
\hline \multirow[t]{2}{*}{ Foreign (B) } & $-0.826^{* * *}$ & -0.287 & 0.208 & 0.295 & $-1.041^{* * *}$ & -0.435 \\
\hline & $(0.257)$ & $(0.327)$ & $(0.601)$ & $(0.726)$ & $(0.284)$ & $(0.366)$ \\
\hline \multirow[t]{2}{*}{$(\mathrm{A}) \times(\mathrm{B})$} & & $-0.040^{* * *}$ & & -0.009 & & $-0.042^{* * *}$ \\
\hline & & $(0.015)$ & & $(0.044)$ & & $(0.016)$ \\
\hline \multirow[t]{2}{*}{ Size } & -0.007 & -0.012 & -0.013 & -0.015 & -0.000 & -0.004 \\
\hline & $(0.062)$ & $(0.062)$ & $(0.161)$ & $(0.161)$ & $(0.067)$ & $(0.067)$ \\
\hline \multirow[t]{2}{*}{ ROE } & $-0.041^{* * *}$ & $-0.041^{* * *}$ & $-0.056^{* * *}$ & $-0.056^{* * *}$ & $-0.037^{* * *}$ & $-0.038^{* * *}$ \\
\hline & $(0.008)$ & $(0.008)$ & $(0.017)$ & $(0.017)$ & $(0.009)$ & $(0.009)$ \\
\hline \multirow[t]{2}{*}{ Debt } & -0.002 & -0.002 & 0.003 & 0.003 & $-0.002^{*}$ & $-0.002^{*}$ \\
\hline & $(0.001)$ & $(0.001)$ & $(0.003)$ & $(0.003)$ & $(0.001)$ & $(0.001)$ \\
\hline \multirow[t]{2}{*}{$\mathrm{FCF}$} & 0.542 & 0.534 & $2.639^{*}$ & $2.643^{*}$ & 0.053 & 0.043 \\
\hline & $(0.754)$ & $(0.754)$ & (1.526) & (1.526) & $(0.857)$ & $(0.856)$ \\
\hline \multirow[t]{2}{*}{ Dividend } & 0.007 & 0.007 & 0.006 & 0.006 & 0.007 & 0.007 \\
\hline & $(0.004)$ & $(0.004)$ & $(0.011)$ & $(0.011)$ & $(0.005)$ & $(0.005)$ \\
\hline \multirow[t]{2}{*}{ AGE } & $0.967^{* * * *}$ & $0.971^{* * *}$ & $1.552^{* * *}$ & $1.555^{* * *}$ & $0.863^{* * *}$ & $0.865^{* * * *}$ \\
\hline & $(0.118)$ & $(0.118)$ & $(0.308)$ & $(0.309)$ & $(0.128)$ & $(0.128)$ \\
\hline $\begin{array}{l}\text { Industrial } \\
\text { Year }\end{array}$ & \multicolumn{6}{|c|}{ Included } \\
\hline $\mathrm{N}$ & 9,337 & 9,337 & 1,625 & 1,625 & 7,712 & 7,712 \\
\hline pseudo $\mathrm{R}-\mathrm{sq}$ & 0.003 & 0.003 & 0.004 & 0.005 & 0.003 & 0.003 \\
\hline
\end{tabular}

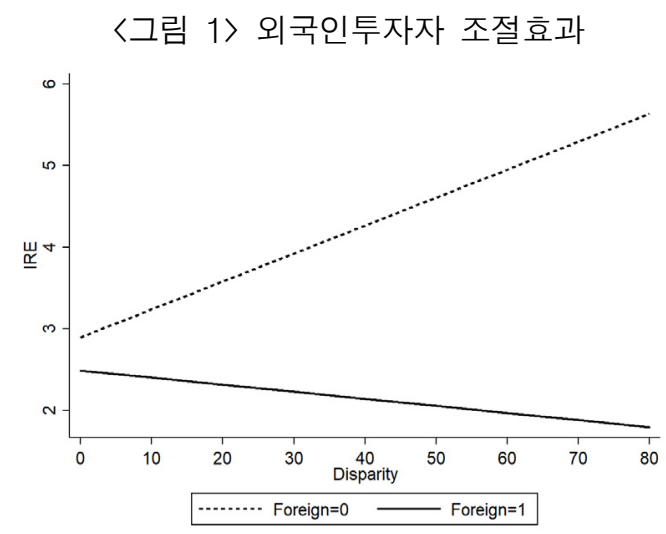

〈그림 2〉1기간 후 외국인투자자 조절효과

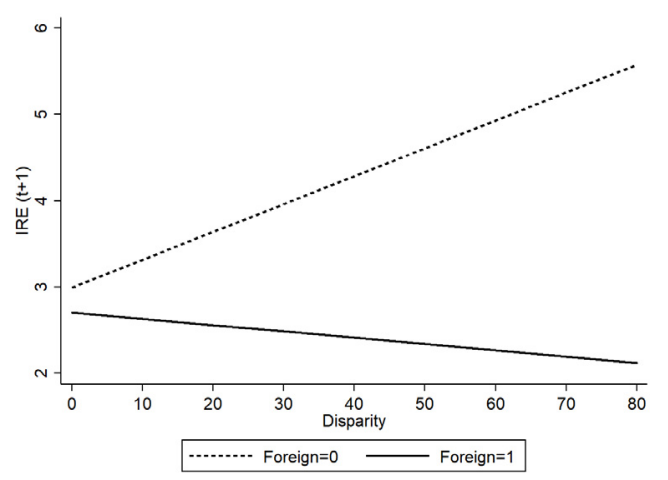


한국증권학회지 제 50 권 3호 (2021)

〈표 11〉 소유지배괴리도와 1기간 후 비사업용부동산 간 외국인투자자의 조절효과: 부동산 관련 및 기업집단 여부

<표 11 >은 소유지배괴리도와 1 기후 비사업용부동산과의 관계에서 업종 및 기업집단 여부에 따른 외국인투자자의 조절효과를 분석한 것으로, 총자산대비 비사업용부동산 비율(IRE)을 종속변수로, 소유권과 지배권의 차이인 소유지배괴리도(Disparity)를 독립변수로 하고, $5 \%$ 이상 대량지분 외국인투자자(Foreign)를 더미변수로 하여 조절변수로 사용하였으며, 총자산의 자연로그값(Size), 자기자본이익률[(ROE: (당기 순이익/자기자본 $\times 100]$, 부채비율[(Debt: (부채/자본×100)], 잉여현금흐름[FCF: (영업현금흐름/매출액) $\times 100$ )], 배당성향[(Dividend: (총배당금/당기순이익)×100] 및 설립부터 해당년도까지 년수의 자연로그값을 사용한 업력(Age)과 연도와 산업더미를 통제변수로 사용하여 토빗회귀분석을 시행한 결과로 *, ** ,**는 각각 $10 \%, 5 \%, 1 \%$ 의 신뢰수준에서 통계적으로 유의적임을 나타내며, 괄호안의 값은 표준오차를 의미한다.

\begin{tabular}{|c|c|c|c|c|c|c|c|c|}
\hline \multirow{2}{*}{$\frac{\text { [devar: } \mathbb{R E} \mathrm{t}+1]}{\text { Disparity (A) }}$} & \multicolumn{2}{|c|}{ 부동산 관련 } & \multicolumn{2}{|c|}{ 부동산 비관련 } & \multicolumn{2}{|c|}{ 대규모기업집단 } & \multicolumn{2}{|c|}{ 비 기업집단 } \\
\hline & $\begin{array}{c}0.051^{*} \\
(0.028)\end{array}$ & $\begin{array}{c}0.064^{* *} \\
(0.030)\end{array}$ & $\begin{array}{c}0.027^{* * *} \\
(0.005)\end{array}$ & $\begin{array}{c}0.032^{* * * *} \\
(0.005)\end{array}$ & $\begin{array}{l}0.035^{* * *} \\
(0.009)\end{array}$ & $\begin{array}{c}0.036^{* * *} \\
(0.010)\end{array}$ & $\begin{array}{l}0.021^{* * *} \\
(0.006)\end{array}$ & $\begin{array}{l}0.026^{* * *} \\
(0.006)\end{array}$ \\
\hline Foreign (B) & $\begin{array}{r}0.422 \\
(1.382)\end{array}$ & $\begin{array}{r}2.199 \\
(1.985)\end{array}$ & $\begin{array}{l}-0.859^{* * *} \\
(0.261)\end{array}$ & $\begin{array}{l}-0.331 \\
(0.332)\end{array}$ & $\begin{array}{l}-0.168 \\
(0.448)\end{array}$ & $\begin{array}{l}-0.057 \\
(0.535)\end{array}$ & $\begin{array}{l}-1.073^{* * *} \\
(0.290)\end{array}$ & $\begin{array}{l}-0.446 \\
(0.374)\end{array}$ \\
\hline$(\mathrm{A}) \times$ & & $\begin{array}{l}-0.120 \\
(0.097)\end{array}$ & & $\begin{array}{l}-0.039^{* * *} \\
(0.015)\end{array}$ & & $\begin{array}{l}-0.011 \\
(0.029)\end{array}$ & & $\begin{array}{l}-0.044^{* *} \\
(0.016)\end{array}$ \\
\hline Size & $\begin{array}{c}-0.419 \\
(0.288)\end{array}$ & & & & $\begin{array}{l}-0.310^{* * *} \\
(0.094)\end{array}$ & $\begin{array}{l}-0.310^{* * *} \\
(0.094)\end{array}$ & $\begin{array}{l}0.446^{* * *} \\
(0.094)\end{array}$ & $\begin{array}{c}0.441^{* * *} \\
(0.094)\end{array}$ \\
\hline ROE & $\begin{array}{l}-0.090^{* * *} \\
(0.033)\end{array}$ & $\begin{array}{l}-0.088^{* * *} \\
(0.033)\end{array}$ & $\begin{array}{l}-0.038^{* * *} \\
(0.008)\end{array}$ & $\begin{array}{l}-0.038^{* * *} \\
(0.008)\end{array}$ & $\begin{array}{l}-0.046^{* * *} \\
(0.016)\end{array}$ & $\begin{array}{l}-0.046^{\text {*** }} \\
(0.016)\end{array}$ & $\begin{array}{l}-0.046^{* * *} \\
(0.008)\end{array}$ & $\begin{array}{l}-0.047^{* *} \\
(0.008)\end{array}$ \\
\hline Debt & $\begin{array}{r}0.007 \\
(0.006)\end{array}$ & $\begin{array}{r}0.008 \\
(0.006)\end{array}$ & $\begin{array}{l}-0.002^{* *} \\
(0.001)\end{array}$ & $\begin{array}{l}-0.002^{* *} \\
(0.001)\end{array}$ & $\begin{array}{r}0.000 \\
(0.002)\end{array}$ & $\begin{array}{r}0.000 \\
(0.002)\end{array}$ & $\begin{array}{l}-0.003^{* *} \\
(0.001)\end{array}$ & $\begin{array}{l}-0.003^{* *} \\
(0.001)\end{array}$ \\
\hline $\mathrm{FCF}$ & $\begin{array}{l}-0.427 \\
(3.573)\end{array}$ & $\begin{array}{l}-0.488 \\
(3.564)\end{array}$ & $\begin{array}{r}0.540 \\
(0.771)\end{array}$ & $\begin{array}{r}0.534 \\
(0.770)\end{array}$ & $\begin{array}{l}-3.994^{* *} \\
(1.645)\end{array}$ & $\begin{array}{l}-4.025^{* *} \\
(1.647)\end{array}$ & $\begin{array}{r}0.904 \\
(0.825)\end{array}$ & $\begin{array}{r}0.918 \\
(0.825)\end{array}$ \\
\hline Divic & $\begin{array}{l}-0.003 \\
(0.024)\end{array}$ & $\begin{array}{l}-0.007 \\
(0.025)\end{array}$ & $\begin{array}{c}0.007^{*} \\
(0.004)\end{array}$ & $\begin{array}{r}0.007 \\
(0.004)\end{array}$ & $\begin{array}{r}0.011 \\
(0.008)\end{array}$ & $\begin{array}{r}0.011 \\
(0.008)\end{array}$ & $\begin{array}{r}0.004 \\
(0.005)\end{array}$ & $\begin{array}{r}0.004 \\
(0.005)\end{array}$ \\
\hline AGE & $\begin{array}{l}-1.873^{* *} \\
(0.762)\end{array}$ & $\begin{array}{l}-1.938^{* *} \\
(0.762)\end{array}$ & $\begin{array}{l}1.000^{* * *} \\
(0.119)\end{array}$ & $\begin{array}{c}1.004^{* * *} \\
(0.119)\end{array}$ & $\begin{array}{c}0.470^{* *} \\
(0.201)\end{array}$ & $\begin{array}{c}0.471^{* *} \\
(0.201)\end{array}$ & $\begin{array}{c}1.020^{* * *} \\
(0.133)\end{array}$ & $\begin{array}{c}1.023^{* *} \\
(0.133)\end{array}$ \\
\hline $\begin{array}{l}\text { Industrial } \\
\text { Year }\end{array}$ & & & & & & & & \\
\hline $\mathrm{N}$ & & & & & & & & 8161 \\
\hline seudo $\mathrm{R}-\mathrm{sq}$ & 0.011 & 0.012 & 0.003 & 0.003 & 0.008 & 0.008 & 0.004 & 0.004 \\
\hline
\end{tabular}

실증분석은 오차항의 이분산성 완화를 위해 강건한 표준오차(Robust Standard Error)를 사용하여 OLS를 통해 분석14)하였다. <표 12>는 비사업용부동산이 기업가치에 미치는 영향을

14) 모형의 강건성을 위하여 소유지배괴리도와 비사업용부동산 모두 양수인 기업(n=3,721)을 대상으로 비사업용부동산이 기업가치에 미치는 영향을 추가적으로 분석하였다. 표본전체 $(\mathrm{n}=11,160)$ 를 대상 으로 한 분석에서는 성장성기준, 부동산 관련업종, 기업집단 여부로 분류한 표본 모두에서 통계적으로 유의하게 음(-)의 결과가 도출된 반면, 소유지배괴리도와 비사업용부동산이 모두 양수인 기업에서는 기업집단표본에서 유의적이지 않은 것으로 나타났다. 또한 유가증권시장 상장기업 $(\beta=-0.031, \mathrm{p}$ $>0.1)$ 과 코스닥 상장기업 $(\beta=-0.352, \mathrm{p}<0.01)$ 으로 분리하여 분석한 결과는 동일한 음 $(-)$ 의 결과가 나왔으나, 유가증권시장 상장기업은 유의적이지 않았다. 
A Study of the Relationship between Corporate Governance and Non-business Real Estate

분석한 결과이다. 성장성 기준, 부동산관련업종 여부, 대규모기업집단 여부의 모든 표본에서 음(-)의 계수가 도출되어 비사업용부동산은 기업가치를 저해하는 것으로 나타났으며, 1 기간 후15) 기업가치에도 일관된 결과를 보였다. 분석결과는 <표 13>에 제시하였다.

\section{〈표 12〉 비사업용부동산이 기업가치에 미치는 영향}

<표 $12>$ 는 기업의 비사업용부동산이 당기의 기업가치에 미치는 영향을 분석한 것으로서, 추정한 기업의 비사업용부동산비율(IRE_hat)을 종속변수로, 기업가치 대용치인 토빈큐[Q: (보통주 시장가치+우선주 장부가치+부채 장부가액)/총자산 장부가액]를 독립변수로 하고, 총자산의 자연로그값(Size), 자기자본 이익률[(ROE: (당기순이익/자기자본)×100], 부채비율[(Debt: (부채/자본 $\times 100)$ ], 잉여현금흐름[FCF: (영업 현금흐름/매출액)×100)], 배당성향[(Dividend: (총배당금/당기순이익)×100] 및 설립부터 해당년도까지 년수의 자연로그값을 사용한 업력(Age)과 지배주주지분율[Owner: (당해 연도말 기준, 지배주주 1 인과 친족지분의 합)], 대형감사인여부[Audit: (금융감독원 명시 4대 회계법인이면 “1”, 그렇지 않으면 “0”)], 연도와 산업더미를 통제변수로 사용하여 OLS를 시행한 결과로 *, ****는 각각 $10 \%, 5 \%, 1 \%$ 의 신뢰수준에서 통계적으로 유의적임을 나타내며, 괄호안의 값은 표준오차를 의미한다.

\begin{tabular}{|c|c|c|c|c|c|c|c|}
\hline [De.Var. Q] & $\begin{array}{l}\text { 전체 } \\
\text { 표본 }\end{array}$ & $\begin{array}{l}\text { 고성장 } \\
\text { 기업 }\end{array}$ & $\begin{array}{l}\text { 저성장 } \\
\text { 기업 }\end{array}$ & $\begin{array}{l}\text { 부동산 } \\
\text { 관련업 }\end{array}$ & $\begin{array}{c}\text { 부동산 } \\
\text { 비관련업 }\end{array}$ & $\begin{array}{l}\text { 대규모 } \\
\text { 기업집단 }\end{array}$ & 비 기업집단 \\
\hline \multirow[t]{2}{*}{ IRE_hat } & $-0.147^{* * *}$ & $-0.126^{* *}$ & $-0.142^{* * *}$ & $-0.081^{*}$ & $-0.150^{* * *}$ & $-0.057^{*}$ & $-0.145^{* * *}$ \\
\hline & (0.015) & $(0.057)$ & $(0.014)$ & $(0.047)$ & $(0.015)$ & $(0.031)$ & $(0.016)$ \\
\hline \multirow[t]{2}{*}{ Size } & $-0.082^{* * *}$ & $-0.040^{*}$ & $-0.080^{* * *}$ & -0.012 & $-0.083^{* * *}$ & $-0.028^{* *}$ & $-0.133^{* * *}$ \\
\hline & $(0.007)$ & $(0.024)$ & (0.008) & (0.018) & $(0.008)$ & $(0.013)$ & $(0.013)$ \\
\hline \multirow[t]{2}{*}{$\mathrm{ROE}$} & $0.003^{* *}$ & 0.003 & 0.000 & -0.002 & $0.004^{* *}$ & $0.016^{* * *}$ & $0.003^{* *}$ \\
\hline & $(0.001)$ & $(0.004)$ & $(0.001)$ & $(0.002)$ & $(0.001)$ & $(0.003)$ & $(0.001)$ \\
\hline \multirow[t]{2}{*}{ Debt } & $-0.002^{* * *}$ & $-0.005^{* * *}$ & $-0.002^{* * *}$ & $-0.001^{* * *}$ & $-0.002^{* * *}$ & $-0.002^{* * *}$ & $-0.002^{* * *}$ \\
\hline & $(0.000)$ & $(0.000)$ & $(0.000)$ & $(0.000)$ & $(0.000)$ & $(0.000)$ & $(0.000)$ \\
\hline \multirow[t]{2}{*}{$\mathrm{FCF}$} & $-0.338^{* *}$ & 0.170 & $-0.447^{* * *}$ & 0.211 & $-0.369^{* *}$ & $0.690^{* * *}$ & $-0.427^{* * *}$ \\
\hline & $(0.152)$ & $(0.345)$ & (0.170) & $(0.261)$ & $(0.157)$ & $(0.265)$ & (0.165) \\
\hline \multirow[t]{2}{*}{ Dividend } & $-0.004^{* * *}$ & $-0.009^{* * *}$ & $-0.002^{* * *}$ & $0.004^{* *}$ & $-0.004^{* * *}$ & 0.001 & $-0.005^{* * *}$ \\
\hline & $(0.001)$ & $(0.002)$ & $(0.001)$ & $(0.002)$ & $(0.001)$ & $(0.001)$ & $(0.001)$ \\
\hline \multirow[t]{2}{*}{ AGE } & $-0.162^{* * *}$ & $-0.229^{* * *}$ & $-0.146^{* * *}$ & $-0.170^{* * *}$ & $-0.153^{* * *}$ & $-0.112^{* * *}$ & $-0.162^{* * *}$ \\
\hline & (0.018) & $(0.047)$ & $(0.019)$ & $(0.043)$ & $(0.018)$ & $(0.028)$ & $(0.020)$ \\
\hline \multirow[t]{2}{*}{ Owner } & $-0.010^{* * *}$ & $-0.016^{* * *}$ & $-0.009^{* * * *}$ & $-0.008^{* * *}$ & $-0.010^{* * * *}$ & $-0.004^{* * *}$ & $-0.011^{* * *}$ \\
\hline & $(0.001)$ & $(0.002)$ & $(0.001)$ & $(0.002)$ & $(0.001)$ & $(0.001)$ & $(0.001)$ \\
\hline \multirow[t]{2}{*}{ Audit } & $0.062^{* *}$ & -0.010 & $0.080^{* * *}$ & $0.248^{* * *}$ & $0.053^{* *}$ & $-0.200^{*}$ & $0.069^{* * *}$ \\
\hline & $(0.025)$ & $(0.068)$ & $(0.027)$ & (0.059) & (0.026) & (0.103) & $(0.026)$ \\
\hline \multirow{2}{*}{\multicolumn{4}{|c|}{$\begin{array}{l}\text { Industrial } \\
\text { Year }\end{array}$}} & \multirow{2}{*}{\multicolumn{4}{|c|}{ Included }} \\
\hline & & & & & & & \\
\hline $\mathrm{N}$ & 11,160 & 2,023 & 9,137 & 367 & 10,793 & 1,404 & 9,756 \\
\hline $\mathrm{R}-\mathrm{sq}$ & 0.077 & 0.089 & 0.072 & 0.242 & 0.073 & 0.124 & 0.078 \\
\hline adj. R-sq & 0.076 & 0.085 & 0.071 & 0.223 & 0.072 & 0.118 & 0.077 \\
\hline
\end{tabular}

15) 소유지배괴리도와 비사업용부동산 모두 양수인 기업을 대상으로 비사업용부동산이 1 기간 후 기업가치에 미치는 영향에서는 부동산 관련업종, 기업집단, 유가증권시장 상장기업은 유의적이지 않은 것으로 나타났다. 


\section{〈표 13〉비사업용부동산이 1기간 후 기업가치에 미치는 영향}

<표 13>은 기업의 비사업용부동산이 1 기 후 기업가치에 미치는 영향을 분석한 것으로서, 추정한 기업의 비사업용부동산비율(IRE_hat)을 종속변수로, 기업가치 대용치인 토빈큐[Q: (보통주 시장가치+우선주 장부가치+부채 장부가액)/총자산 장부가액]를 독립변수로 하고, 총자산의 자연로그값(Size), 자기자본 이익률[(ROE: (당기순이익/자기자본)×100], 부채비율[(Debt: (부채/자본×100)], 잉여현금흐름[FCF: (영업현금흐름/매출액) $\times 100$ )], 배당성향[(Dividend: (총배당금/당기순이익)×100] 및 설립부터 해당년도 까지 년수의 자연로그값을 사용한 업력(Age)과 지배주주지분율[Owner: (당해 연도말 기준, 지배주주 1 인과 친족지분의 합)], 대형감사인여부[Audit: (금융감독원 명시 4대 회계법인이면 “1”, 그렇지 않으면 “0”)], 연도와 산업더미를 통제변수로 사용하여 OLS를 시행한 결과로, *, ${ }^{* *},{ }^{* * *}$ 는 각각 $10 \%, 5 \%, 1 \%$ 의 신뢰수준에서 통계적으로 유의적임을 나타내며, 괄호안의 값은 표준오차를 의미한다.

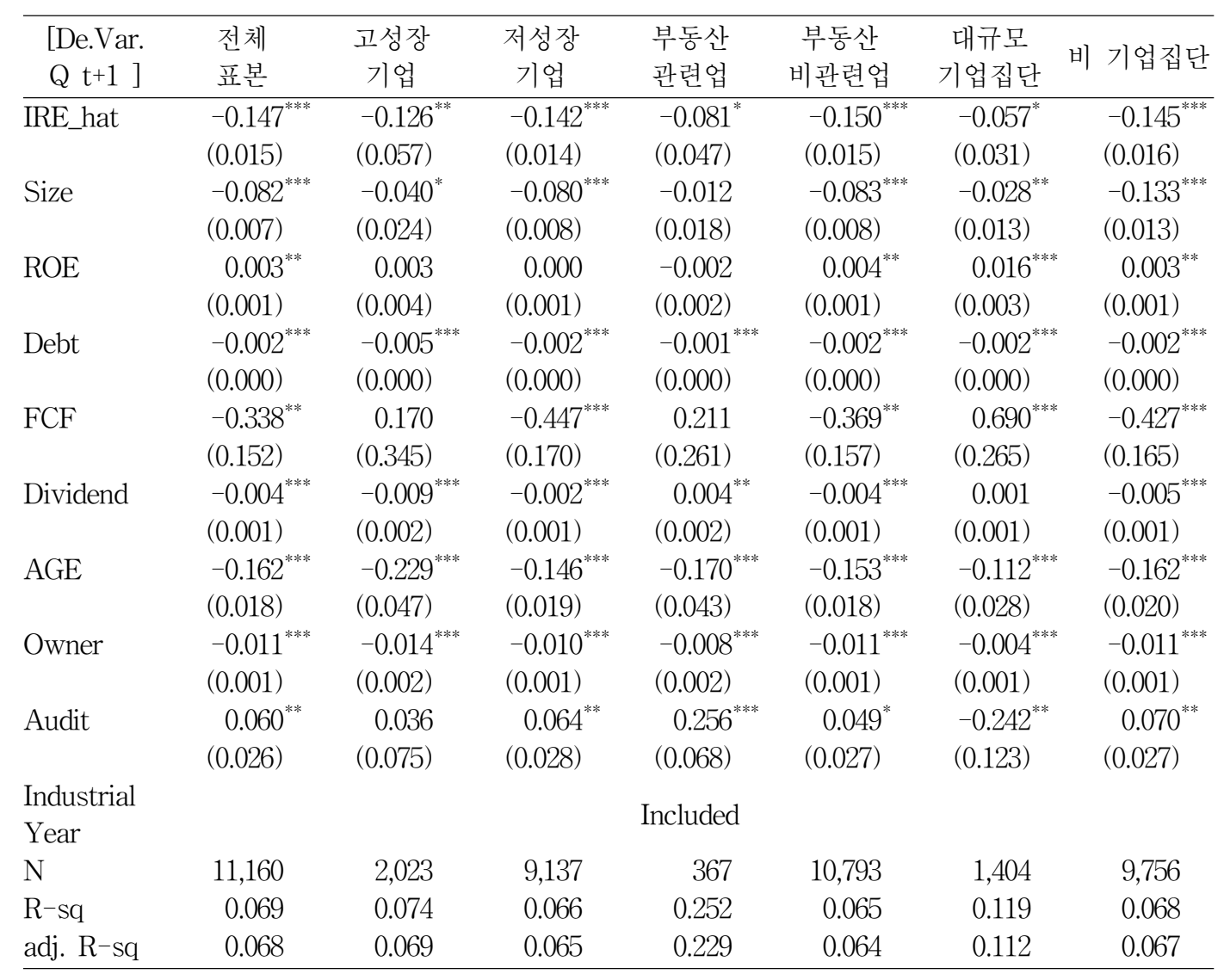

소유지배괴리도가 높을수록 기업의 비사업용부동산이 증가하고, 비사업용부동산이 기업가치에 부정적인 요인으로 작용한다는 본 연구결과는, 부동산 보유 또는 취득이 기업가치에 음(-)의 영향을 미친다는 기존의 선행 연구결과(Kim and Jung, 1993; Kim and Kim, 2015; Kim and Pae, 2017; Kim and Lee, 2018; Lee, 2018; Lim and Kim, 2018; Choi et al., 2019; Noh and Son, 2019)와 같은 맥락으로 이해 할 수 있다. 이는 비사업용부동산이 소유경영자의 사적이익을 위한 수단으로 활용될 수 있는 대리인 문제의 원인으로 작용할 수 있음을 의미한다. 


\section{3 강건성 검증}

기업가치나 경영성과 하락 등으로 인해 기업은 대체투자 수단으로서 비사업용 부동산을 선택할 수 있다. 만약 대체투자 수단으로서 비사업용 부동산에 투자하고 이에 대한 결과로 기업가치가 상승한다면 비사업용 부동산은 기업의 수익원으로서 중요한 자원이 될 것이다. 이에 대한 검증을 위해 2011년부터 2017년까지 금융업, 상장폐지 및 재무자료 미확인 기업을 제외하고 유가증권시장 상장기업 중 비사업용부동산을 보유한 제조업 총 2,640 개를 표본으로 재구성하여, 사업용 자산 대비 비사업용부동산의 수익성과 대체투자 수단 여부 및 비사업용부동산의 기업가치 관련성을 검증하였다. 재무 및 기업자료는 한국상장회사협의회 제공 DB인 TS-2000을 통해, 임대사업 수익과 비용자료는 금융감독원 공시사이트(dart.fss.or.kr)에 공시된 사업보고서의 재무제표 주석을 통해 수집하였다.

우선 표본기간 중 사업용 자산 대비 수익률(ROA)과 비사업용부동산 대비 수익률(ROIRE)을 비교하였다. ROA는 당해 연도 정상영업이익에서 비사업용부동산 이익을 차감한 값을 당해 연도 총자산의 평균에서 비사업용부동산의 평균을 차감한 값으로 나누어 산출하였으며, ROIRE는 당해 연도 임대수익에서 임대비용을 차감한 값을 당해 연도 비사업용부동산의 기초기말 평균으로 나누어 산출하였다. <표 14>는 두 자산에 대한 수익률을 비교한 표이다. ROA는 7년 간 3.14\% $3.99 \%$ 이고, ROIRE는 $0.61 \% \sim 1.70 \%$ 로 사업용 자산으로부터 발생한 이익이 비사업용부동산 으로부터 발생한 이익에 비해 $2.29 \% \mathrm{P} \sim 2.53 \% \mathrm{P}$ 만큼 높은 것으로 나타나 비사업용부동산에 대한 수익성이 본업수익 보다 낮다는 것을 알 수 있다. 뿐만 아니라 비사업용부동산을 보유하고 있음에도 수익과 비용이 전혀 없는 기업이 2,091개로 $79 \%$ 에 달하는 것으로 나타났다. ${ }^{16)}$

〈표 14〉연도별 ROA와 비사업용부동산 이익률(ROIRE) 비교: 유가증권시장 상장기업 중 비사업용부동산 보유 기업 대상

\begin{tabular}{lrrrrrrrr}
\hline \multicolumn{1}{c}{ 구분 } & 평균 & 2011 & 2012 & 2013 & 2014 & 2015 & 2016 & 2017 \\
\hline $\mathrm{ROA}(\%)$ & 3.54 & 3.99 & 3.20 & 3.14 & 3.36 & 3.63 & 3.84 & 3.59 \\
$\mathrm{ROIRE}(\%)$ & 1.12 & 1.02 & 1.14 & 1.58 & 1.70 & 1.01 & 0.81 & 0.61 \\
\hline $\mathrm{n}$ (합계) & 2,640 & 364 & 370 & 371 & 376 & 383 & 380 & 396 \\
\hline
\end{tabular}

추가로 기업가치 하락이 비사업용부동산에 대한 유인으로 작용하는지를 규명하기 위해 1 기간 전 기업가치 대용치인 토빈 $\mathrm{Q}$ 를 독립변수로, 당기의 비사업용부동산비율을 종속변수로 하여 기업규모 등 기업요인과 산업, 연도더미를 통제한 모델을 아래와 같이 설정하여 토빗 회귀분석을 시행하였다.

$$
\begin{aligned}
\text { Tobit }: \text { IRE }_{i, t}= & \beta_{0}+\beta_{1} Q_{i, t-1}+\beta_{2} \text { Size }_{i, t-1}+\beta_{3} \text { ROE }_{i, t-1}+\beta_{4} \text { Dividend }_{i, t-1} \\
& +\beta_{5} \text { Debt }_{i, t-1}+\beta_{6} F C F_{i, t-1}+\beta_{7} \text { Age }_{i, t-1}+\operatorname{Year}(\text { dum }) \\
& + \text { Industrial }(\text { dum })+\varepsilon_{i . t-1}
\end{aligned}
$$

16) 2011년부터 2017년까지 7년간 ROIRE가 0보다 큰 기업은 512개, 0인 기업은 2,091개, 0보다 작은 기업은 37개로 비사업용부동산으로 발생하는 수익이 없거나 손실인 기업이 $80.6 \%$ 로 대부분을 차지했다. 
식 (4)에서 추정한 비사업용부동산비율을 독립변수로 하여 1 기간 후 기업가치에 미치는 영향을 분석하기 위해 식 (5)의 모형을 설정하고 강건한 표준오차(robust standard error) 방법의 OLS를 시행, 회귀분석하였다.

$$
\begin{aligned}
\text { OLS: } Q_{i, t+1}= & \beta_{0}+\beta_{1} \widehat{I R E}_{i, t}+\beta_{2} \text { Size }_{i, t}+\beta_{3} R O E_{i, t}+\beta_{4} \text { Dividend }_{i, t} \\
& +\beta_{5} \operatorname{Debt}_{i, t}+\beta_{6} F C F_{i, t}+\beta_{7} \text { Age }_{i, t}+\operatorname{Year}(\text { dum }) \\
& + \text { Industrial }(\text { dum })+\varepsilon_{i, t}
\end{aligned}
$$

분산팽창계수(VIF)는 2.83으로 우려할 수준의 다중공선성 문제는 없는 것으로 확인 되었다. 분석 결과, 기업가치와 비사업용부동산 간 음(-)의 계수가 나타났는데, 이는 기업가치 하락이 비사업용부동산에 대한 유인이 될 수 있음을 보여주는 결과라 할 수 있다. 그러나 비사업용 부동산은 1 기간 후의 기업가치에 음(-)의 영향을 미치는 것으로 나타났고, 이러한 결과는 비사업용부동산이 기업가치를 저하시키는 자원임을 시사한다. 결과는 <표 $15>$ 에 제시하였다.

〈표 15〉기업가치와 비사업용부동산과의 관계: 유가증권시장 상장기업 중 비사업용부동산 보유 기업 대상

\begin{tabular}{lcc}
\hline & Tobit: IRE $(\mathrm{t})$ & OLS: $\mathrm{Q}(\mathrm{t}+1)$ \\
\hline $\mathrm{Q}(\mathrm{t}-1)$ & $-0.054^{* *}$ & \\
& $(0.258)$ & $-0.283^{* * *}$ \\
IRE & & $(0.043)$ \\
\hline Size (t-1), (t) & $-1.244^{* * *}$ & $-0.404^{* * *}$ \\
& $(0.138)$ & $(0.055)$ \\
ROE (t-1), (t) & $-0.017^{*}$ & $-0.005^{* * *}$ \\
& $(0.010)$ & $(0.002)$ \\
Dividend (t-1), (t) & 0.000 & 0.000 \\
& $(0.003)$ & $(0.000)$ \\
Debt (t-1), (t) & -0.000 & $-0.000^{* * *}$ \\
& $(0.001)$ & $(0.000)$ \\
FCF (t-1), (t) & 0.093 & 0.301 \\
& $(0.609)$ & $(0.188)$ \\
Age (t-1), (t) & $1.092^{* * *}$ & $0.268^{* * *}$ \\
& $(0.272)$ & $(0.055)$ \\
Year, Industrial & Included & Included \\
\hline $\mathrm{N}$ & 1837 & 1760 \\
$\mathrm{R}-\mathrm{sq}$ & & 0.104 \\
adj. R-sq & & 0.101 \\
pseudo R-sq & 0.008 & \\
\hline
\end{tabular}

비사업용부동산은 본업에 비해 수익성이 낮을 뿐 아니라 기업가치를 하락시키는 것으로 제시됨에 따라 대체투자 수단으로서의 비사업용부동산은 주주의 이익을 저해할 수 있는 
A Study of the Relationship between Corporate Governance and Non-business Real Estate

비효율적인 자원이라고 할 수 있으며, 뿐만 아니라 사업용자산 대비 비사업용부동산의 낮은 이익을 감안할 때 비사업부동산이 대리인문제를 야기할 수 있는 자원으로 작동할 수 있음을 확인하였다.

\section{5. 결론}

본 연구는 기업의 시세차익 목적 또는 임대수익 목적의 비사업용부동산 보유로 인한 사회적 논란을 배경으로 소유지배괴리도와 기업의 비사업용부동산과의 관계를 분석하고 소유지배 괴리도와 비사업용부동산의 관계에서 기관투자자의 역할과 비사업용부동산의 기업가치 관련성을 밝히고자 하였다. 연구방법은 1 단계로 소유지배괴리도와 비사업용부동산 간의 관계를 회귀분석 하였고, 2 단계로 1 단계에서 추정된 비사업용부동산을 독립변수로 하여 기업가치 관련성에 대한 분석을 수행하였다.

분석 결과, 첫째 소유지배괴리도는 비사업용부동산에 양(+)의 영향을 미치는 것으로 나타났다. 즉 소유지배괴리도가 증가할수록 기업의 비사업용부동산이 증가하는 것으로 나타났다. 추가분석 결과 이는 성장이 상대적으로 정체된 저성장 기업의 경우 일관되게 유의한 양(+)의 관계가 나타났다. 고성장기업은 통계적으로 유의하지 않은 결과가 나타나 비사업용부동산에 대한 유인이 작용하지 않는 것으로 확인되었다. 이는 소유지배괴리도와 관계없이 본업을 통한 수익이 비사업용부동산에 대한 수익보다 높기 때문인 것으로 해석된다.

둘째, 외국인투자자는 소유지배괴리도가 비사업용부동산의 상승요인으로 작용하는 과정에서 이를 완화(-)시키는 견제효과가 있음을 규명하였다. 이러한 음(-)의 조절효과는 저성장기업, 부동산 비관련업종, 대규모기업집단 비소속기업에 일관되게 나타났으며, 고성장기업, 부동산 관련업종 및 대규모기업집단에서는 유의적이지 않은 것으로 나타났다. 이는 성장성, 업종 관련성, 제도적 장치에 따라 소유경영자의 지분에 따른 비사업용부동산의 유인에 대한 외국인투자자의 모니터링은 차별적일 수 있음을 의미한다.

셋째, 기업의 비사업용부동산은 기업가치를 하락(-)시키는 것으로 나타났다. 이는 비사업용 부동산이 대체투자 수단으로서도 기능하지만, 사업용 자산대비 기회손실을 가져오는 비효율적인 자산일 수도 있음을 시사한다.

넷째, 본 연구결과의 강건성 검증을 위해 비사업용부동산이 대체투자 수단임을 전제로 기업가치와 비사업용부동산 상호간의 영향에 대해 추가로 분석하였다. 분석결과, 1 기간 전의 기업가치 하락이 비사업용부동산에 대한 유인으로 작용하지만 1 기간 후에는 기업가치를 하락시키는 것으로 나타났다. 이러한 결과는 비사업용부동산이 수익의 원천으로 사용되기 보다는 경영자의 사적이익 향유를 위한 수단이 될 개연성을 보여준 것이라 할 수 있다.

본 연구는 소유 및 지배구조 관점에서 소유지배괴리도와 기업의 비사업용부동산에 대한 관계를 규명하고자 하였다. 기존연구는 기업부동산 전체에 대해 또는 기업부동산 사용목적별로 기업가치에 미치는 영향을 분석하는 데 국한되었다. 그러나 부동산의 사용목적별 기업가치의 영향은 국제회계기준 도입 전의 자료사용으로 자료누락이나 부동산의 사용목적에 대한 신뢰성 
의문으로 연구에 한계가 존재한다고 할 수 있다. 이에 반해 본 연구는 국제회계기준 도입 이후의 자료를 사용함으로써 비사업용부동산에 대한 자료 및 연구결과의 신뢰성을 높였으며, 더불어 기업의 성장성, 관련업종, 대규모기업집단으로 구분하여 분석함으로써 기업의 특성을 반영하고, 비사업용부동산을 매개로 한 소유지배괴리에 따른 대리인문제의 가능성 검증 및 외국인투자자의 감시효과까지 분석함으로써 기존의 연구를 정치하게 확장하였다는 점에서 차별적이라 할 수 있다.

본 연구결과에서 주지하듯이 비사업용부동산은 대리인문제 가능성을 내포하고 있으며, 법인세 절감효과를 기대하기 어렵고 기업가치 제고에도 기여하기 어려운 경영자원이라 할 수 있다. 따라서 기업은 비사업용부동산이 대리인비용의 원천이 될 수 있다는 점을 감안하여 비사업용 부동산에 대한 의사결정에 신중한 판단이 필요하며, 증권거래소 등 관련기관은 비사업용부동산의 취득.처분에 대한 자율공시를 의무공시로 개정할 뿐만 아니라 비사업용부동산의 임대도 공시사항에 포함시키는 내용의 검토가 필요할 것으로 본다.

한편 기업은 부동산을 사업용과 비사업용으로 혼용할 수 있다. 예를 들어 한 건물 내 일정부분은 사업용으로 일정부분은 비사업용으로 사용할 경우가 있을 수 있고, 일시적으로 비사업용 부동산으로 계상 할 수도 있다. 이 경우, 사업용인지 비사업용인지에 대한 명확한 구분과 일시적 사용인지 장기사용인지 여부에 대해 명확한 구분이 필요한데 본 연구에서 이러한 부분까지 반영하지 못한 점은 연구의 한계라 할 수 있다.

더불어 국제회계기준에서는 비사업용부동산에 대해 공정가치모형이나 원가모형으로 측정 하도록 하고 있는데, 기업부동산을 측정모형별로 사업용과 비사업용으로 나누어 분석한 후속연구가 진행된다면 본 연구를 더욱 확장할 뿐 아니라 실무적, 제도적 및 정책적으로 많은 시사점을 제시 할 수 있을 것으로 본다. 
A Study of the Relationship between Corporate Governance and Non-business Real Estate

\section{References}

Abel, A. B., and O. J. Blanchard, 1986, The Present Value of Profits and Cyclical Movements in Investment, Econometrica, Vol. 54, pp. 249-273.

Aggarwal, R., I. Erel, M. Ferreira, and P. Matos, 2011, Does Governance Travel Around the World? Evidence from Institutional Investors, Journal of Financial Economies, Vol. 100, pp. 154-181.

Anderson, R. C., and D. M. Reeb, 2003, Founding-family Ownership, Corporate Diversification, and Firm leverage, The Journal of Law and Economics, Vol. 46 (2), pp. 653-684.

Ball, R., 2009, Market and Political/Regulatory Perspectives on the Recent Accounting Scandals, Journal of Accounting Research, Vol. 47 (7), pp. 277-323.

Barlow, N., and E. Lawson, 1990, Real Estate's Vital Role in Corporate Finance, Journal of Corporate Accounting and Finance, Vol. 1 (4), pp. 361-365.

Bebchuk, L., A. Cohen, and A. Ferrell, 2009, What Matters in Corporate Governance?, Review of Financial Studies, Vol. 22, pp. 783-827.

Berger, P. G. and E. Ofek, 1995, Diversification's Effect on Firm Value, Journal of Financial Economics, Vol. 37, pp. 39-65.

Bhide, A., 1994, Efficient Markets, Deficient Governance, Harvard Business Review, Vol. 72 (6), pp. 129-139.

Bizjak, J. M., J. A. Brickley, and J. L. Coles, 1993, Stock-based Incentive Compensation and Investment Behavior, Journal of Accounting and Economies, Vol. 16 (1-13), pp. 349-372.

Blanchard, O. J., F. Lopez-de-Silanes, and A. Shleifer, 1994, What Do Firms Do with Cash Windfall?, Journal of Financial Economics, Vol. 36 (3). pp. 337-360.

Booth, M., 2000, How Corporate Real Estate Affects Shareholder Value, Journal of Corporate Real Estate, Vol. 2 (1), pp. 19-28.

Bushee, B. J., 1998, The Influence of Institutional Investors on Myopic R\&D Investment Behavior, Accounting Review, Vol. 73 (3), pp. 305-333.

Choi, H. M., and Y. G. Cho, 2011a, Control-Ownership Disparity and Firm Value: The Moderating Effect of Foreign Ownership, International Business Review, Vol. 15 (3), pp. 93-108.

Choi, H. M., and Y. G. Cho, 2011b, Control-Ownership Disparity and R\&D Investment, Journal of Korea Academia-Industrial Cooperation Society, Vol. 12 (12), pp. 5558-5563.

Choi, H. M., and Y. G. Cho, 2012, Agency Problem of Control-Ownership Disparity and Fixed Asset Investment, Journal of Strategic Management, Vol. 15 (3), pp. 1-18.

Choi, J. H., and J. W. Lee, 2008, An Empirical Study on the Association between Audit 
한국증권학회지 제 50 권 3호 (2021)

Quality, Earning Quality, and Firm Value, Study on Accounting, Taxation \& Auditing, Vol. 48, pp. 109-144.

Choi, J. Y., S. H. Ro, and J. Y. Kim, 2019, A Study on the Influence of Corporate Real Estate and Firm Value in the Corporate Life Cycle, Review of Real Estate and Urban Studies, Vol. 12 (1), pp. 21-43.

Chung, R., M. Firth, and J. Kim, 2002, Institutional Monitoring and Opportunistic Earnings Management, Journal of Corporate Finance, Vol. 8 (1), pp. 29-48.

Claessens, S., S. Djankov, and J. H. Fan, 2002, Disentangling the Incentive and Entrenchment Effect of Large Shareholder, Journal of Finance, Vol. 57 (6), pp. 2741-2771.

Claessens, S., S. Djankov, and L. H. Lang, 2000, The Separation of Ownership and Control in East Asian Corporations, Journal of Financial Economics, Vol. 58 (1-2), pp. 81-112.

Fazzari, S., R. G. Hubbard, and B. C. Petersen, 1987, Financing Constraints and Corporate Investment(No. w2387), National Bureau of Economic Research.

Ferreira, M. A., and P. Matos, 2008, The Colors of Investors' Money: The Role of Institutional Investors around the World, Journal of Financial Economics, Vol. 88 (3), pp. 499-533.

Gillan, S., and L. T. Starks, 2003, Corporate Governance, Corporate Ownership, and the Role of Institutional Investors: A Global Perspective, Journal of Applied Finance, Vol. 13 (2), pp. 4-22.

Hartzell, J. C., and L. T. Starks, 2003, Institutional Investors and Executive Compensation, Journal of Finance, Vol. 58 (6), pp. 2351-2374.

He, W., and J. Shen, 2014, Do Foreign Investors Improve Informational Efficiency of Stock Prices? Evidence from Japan, Pacific-Basin Finance Journal, Vol. 27, pp. 32-48.

Hill, M., 2001, Corporate Real Estate: Its Role in Maximizing Shareholder Value, Journal of Corporate Real Estate, Vol. 3 (4), pp. 335-345.

Jensen, M. C., 1986, Agency Costs of Free Cash Flow, Corporate Finance, and Takeovers, The American Economic Review, Vol. 76 (2), pp. 323-329.

Jensen, M. C., and K. J. Murphy, 1990, Performance Pay and Top-management Incentives, Journal of Political Economy, Vol. 98 (2), pp. 225-264

Jensen, M. C., and W. H. Meckling, 1976, Theory of the Firm: Managerial Behavior, Agency Costs, and Ownership Structure, Journal of Financial Economies, Vol. 3 (4), pp. 305-360.

Jeon, J. Q., and C. M. Moffett, 2010, Herding by Foreign Investors and Emerging Market Equity Returns: Evidence from Korea, International Review of Economics \& Finance, Vol. 19 (4), pp. 698-710.

Jung, C. S., 2015, A Study on the Effects of Controlling Shareholders' Ownership and the Sensitivity between Controlling Shareholders' Wealth and Firms' Performance on the 
A Study of the Relationship between Corporate Governance and Non-business Real Estate

Risk and Tobin's Q of Firms, Korean Management Review, Vol. 44 (1), pp. 81-102. Kang, W. C., and S. S. Kho, 2015, An Empirical Study on the Influence of the Corporate Real Estate on the Value of Firm, The Journal of Business Education, Vol. 29 (1), pp. 191-214.

Khanna, T., and K. Palepu, 1999, Emerging Market Business Groups, Foreign Investors, and Corporate Governance(No. 6955), National Bureau of Economic Research.

Kim, A. L., and M. H. Cho, 2008, Types of Foreign Investors, and Dividend and Investment Policy: An Empirical Study of Korean Firms, Journal of Strategic Management, Vol. 11 (1), pp. 25-42.

Kim, B. M., and C. H. Lee, 2018, The Relationship on Corporate Governance, Corporate Real Estate Holding Policies and Firm Value: Focus on IFRS Adoption, Journal of Digital Convergence, Vol. 16 (9), pp. 125-132.

Kim, D. H., D. W. Kim, and B. G. Kim, 2010, Ownership-control Disparity and Corporate Diversification in Korea: Perspectives of Agency Problem, Korean Journal of Financial Engineering, Vol. 9 (3), pp. 123-147.

Kim, D. W., and B. G. Kim, 2015, Corporate Investment Real Estate and Corporate Value: Evidence from Korean Listed Companies, Review of Business and Economics, Vol. 28 (6), pp. 2523-2542.

Kim, H. S., and S. H. Park, 2017, The Effects of Foreign Investors on Firms' Crash Risk, Korean Journal of Financial Studies, Vol. 46 (4), pp. 839-877.

Kim, I. J., J. Eppler-Kim, W. S. Kim, and S. J. Byun, 2010, Foreign Investors and Corporate Governance in Korea, Pacific-Basin Finance Journal, Vol. 18 (4), pp. 390-402.

Kim, J. B., Y. Li, and I. Zhang, 2011b, CFO vs. CEO: Equity Incentives and Crashes, Journal of Financial Economics, Vol. 101 (3), pp. 713-730.

Kim, J. S., and K. W. Jung, 1993, A Study on the Firm's Real Estate Holding and Firm Value, The Korean Journal of Financial Management, Vol. 10 (2). pp. 53-81.

Kim, J. T., and S. J. Pae, 2017, A Study on the Value Relevance of the Separate and the Consolidated Financial Statements: Focus on Comprehensive Income, Korean Journal of Business Administration, Vol. 30 (12), pp. 2173-2194.

Kim, M. C., D. W. Kim, and B. G. Kim, 2015, Agency Problem, Corporate Governance, and Corporate Real Estate Policy, Review of Business and Economics, Vol. 28 (2), pp. 785-808.

Kim, Y. G., S. C. Jung, and J. S. Oh, Real Estate Economics, Hyungseul Publishing, 2007.

Kim, Y. H., and S. C. Jung, 2011, A Study on the Effects of Domestic and Foreign Outside Blockholders on Firm's Investment Policy, Asian Review of Financial Research, Vol. 24 (3), pp. 789-817. 
한국증권학회지 제 50 권 3 호 (2021)

Kothari, S. P., S. Shu, and P. D. Wysocki, 2009, Do Managers Withhold Bad News?, Journal of Accounting Research, Vol. 47(1), pp. 241-276.

Krumm, P. J., and J. de Vries, 2003, Value Creation through the Management of Corporate Real Estate, Journal of Property Investment and Finance, Vol. 21 (1), pp. 61-72.

Kwon, T. H., 2012, Analysis on the Business Groups and Performance, The Korean Journal of Financial Management, Vol. 29 (4), pp. 1-28.

Kwon, T. H., 2016, A Firm's Growth and its Diversification Effects, Korean Journal of Financial Studies, Vol. 45 (4), pp. 811-836

Kwon, T. H., and J. W. Park, 2007, Valuation Effect of Across firm and Within-firm Diversification, Asian Review of Financial Research, Vol. 20 (2), pp. 93-124.

Kwon, T. H., and S. M. Choi, 2013, Disparity of Control and Ownership and Earnings Quality of Holding Companies in Chaebul, Korean Journal of Financial Engineering, Vol. 12 (2), pp. 97-126.

La Porta, R., F. Lopez-de-Silanes, A. Shleifer, and R. Vishny, 2002, Investor Protection and Corporate Valuation, The Journal of Finance, Vol. 57 (3), pp. 1147-1170.

La Porta, R., F. Lopez-de-Silanes, and A. Shleifer, 1999, Corporate Ownership around the World, The Journal of Finance, Vol. 54 (2), pp. 471-517.

Lee, C. H., 2018, The Relationship between Real Estate Holdings and Firm's Value: Comparisons between KOSPI and KOSDAQ Companies, Journal of the Korea Convergence Society, Vol. 9 (11), pp. 353-361.

Lee, C. S., Real Estate Principles and Practices, Hyungseul Publishing, 2007.

Lee, H. Y., and M. H. Cho, 2009, An Empirical Study on the Influence of the Possession and Investment Estate on the Value of Firm, Korean Corporation Management Review, Vol. 16 (4), pp. 67-81.

Lee, J. H., and H. S. Byun, 2016a, The Effect of Product Market Competition on Corporate Real Estate and the Value Relevance of It, Journal of the Korea Real Estate Analysts Association, Vol. 22 (3), pp. 61-80.

Lee, J. H., and H. S. Byun, 2016b, Does Competitive Threats Discipline Controlling Shareholders?: Focusing on the Incentive to Pursue a Private Benefit Based on the Ownership-Control Disparity, Korean Journal of Financial Studies, Vol. 45 (3). pp. 671-712.

Lee, J. J., Land Economics, Parkyoungsa, 2019.

Lemmon, M. L., and K. V. Lins, 2003, Ownership Structure, Corporate Governance and Firm Value: Evidence from the East Asian Financial Crisis, Journal of Finance, Vol. 58 (4), pp. $1451-1468$.

Lim, B. K., and C. K. Kim, 2018, A Study on the Effect of Real Estate Acquisitions and 
A Study of the Relationship between Corporate Governance and Non-business Real Estate

Sales on Firm Value, The Journal of the Korea Contents Association, Vol. 18 (7), pp. $49-63$

Lim, S. G., M. Y. Lee, and I. I. Hwang, 2014, The Investment Efficiency of Firms Belonging to Large Business Conglomerates, Korean Accounting Review, Vol. 39 (3), pp. 91-134.

Loderer, C., and K. Martin, 1997, Executive Stock Ownership and Performance Tracking Faint Traces, Journal of Financial Economies, Vol. 45 (2), pp. 223-255.

McConnell, J., and C. Muscarella, 1985, Corporate Capital Expenditure Decisions and Market Value of the Firm, Journal of Financial Economics, Vol. 14 (3), pp. 399-422.

Mian, R., and K. Nagata, 2015, Foreign Institutional Ownership and the Valuation Effect of Investment and Payout Decision, Journal of Finance and Economies, Vol. 3 (5), pp. $97-104$.

Mitton, T., 2006, Stock Market Liberalization and Operating Performance at the Firm Level, Journal of Financial Economics, Vol. 81 (3), pp. 625-647.

Myers, S., 1977, Determinants of Corporate Borrowing, Journal of Financial Economics, Vol. 5 (1), pp. 147-176.

Noe, T. H., 2002, Institutional Activism and Financial Market Structure, Review of Financial Studies, 15, pp. 289-318.

Noh, G. J., and P. D. Son, 2019, Effects of Own Real and Investment Real Estate on Firm Value of KOSDAQ Manufacturing Companies, Korean Management Consulting Review, Vol. 19 (1), pp. 185-192.

Park, H. J., H. A. Shin, and W. S. Choi, 2004, The Korean Firms' Agency Costs and Firm Value: Role of Foreign Investors' Equity Ownership, Korean Management Review, Vol. 33 (2), pp. 655-682.

Park, K. S., 2017, Review of Corporate Governance Research and its Implications for Korea, Korean Management Review, Vol. 46 (3). pp. 625-662.

Park, K. S., and E. J. Lee, 2006, The Role of Foreign Investors on the Management and Corporate Governance of Korean Companies, Review of Financial Economics, Vol. 20 (2), pp. 73-113.

Shin, H. H., J. H. Chang, and S. C. Lee, 2004, Outside Monitors and Firm Value, Asian Review of Financial Research, Vol. 17 (1), pp. 41-72.

Shleifer, A., and R. W. Vishny, 1986, Large Shareholders and Corporate Control, Journal of Political Economy, Vol. 94 (3), pp. 461-488.

Shleifer, A., and R. W. Vishny, 1997, A Survey of Corporate Governance, The Journal of Finance, Vol. 52 (2), pp. 737-783.

Shleifer, A., and R. W. Vishny, 1989, Managerial Entrenchment, The Case of Manager-Specific 
한국증권학회지 제 50 권 3 호 (2021)

Investments, Journal of Financial Economics, Vol. 25, pp. 123-139.

Stulz, M., 1990, Managerial Discretion and Optimal Financing Policies, Journal of Financial Economics, Vol. 26 (1), pp. 3-27.

Sul, W. S., and S. A. Kang, 2006, Foreign Institutional Investors and Firm's Managerial Decision Making, Korea Trade Review, Vol. 31 (4), pp. 99-128.

Yoon, S. M., 2005, The Effects of Separation of Ownership and Control on Innovative Activity, The Korean Journal of Economic Studies, Vol. 53 (1), pp. 71-96.

Yoon, Y. S., and S. P. Kim, 1999, The Effect of Business Diversification and Agency Problem on Firm Value, Asian Review of Financial Research, Vol. 12 (1), pp. 1-37. 